\title{
Metáforas del amor en la poesía de la Grecia antigua (II): De la tragedia ática a la poesía helenística
}

\author{
Pilar Hualde Pascual ${ }^{1}$
}

Recibido: 15 de mayo de 2017 / Aceptado: 13 de diciembre de 2017

Resumen. Partiendo del concepto de metáfora cognitiva, que complementa al más conocido de metáfora literaria, y analizando la base conceptual que a ambas subyace, pretendemos un cuidadoso análisis de los textos griegos, sin olvidar la importancia fundamental del contexto cultural en que estos surgen, para obtener una mejor comprensión de la forma en que se conceptualizaba el sentimiento amoroso en la Grecia antigua. En este caso nos centramos en una selección de textos de tragedia ática y poesía helenística

Palabras clave: metáfora, cognitivismo, amor, tragedia ática, poesía helenística.

[en] Love metaphors in ancient Greek poetry (II): From attic tragedy to Hellenistic poetry

\begin{abstract}
Based on the concept of cognitive metaphor, which complements the best-known literary metaphor, and analyzing the conceptual basis underlying both, we seek a careful analysis of the Greek texts, without forgetting the fundamental importance of the cultural context in which they arise, in order to obtain a better understanding of the way in which the sentiment of love was conceptualized in ancient Greece. In this case we focus on a selection of Attic tragedy and Hellenistic poetry texts.
\end{abstract}

Keywords: metaphor, cognitivism, love, Attic Tragedy, Hellenistic Poetry.

Sumario. 1. Introducción. 2. Metáforas de amor en la tragedia ateniense. 3. Metáforas de amor en la obra de Sófocles. 4. Eurípides: Hipólito y Medea. 5. Poesía helenística. 6. Conclusiones. 7. Apéndice: Cuadros de metáforas del amor en la poesía griega antigua.

Cómo citar: Hualde Pascual, P. (2018) Metáforas del amor en la poesía de la Grecia antigua (II): De la tragedia ática a la poesía helenística, en Cuadernos de Filología Clásica. Estudios griegos e indoeuropeos $28,41-81$. 


\section{Introducción}

En un trabajo anterior en esta misma revista ${ }^{2}$ planteamos el estudio de las metáforas amorosas presentes en los textos griegos de épica y lírica arcaicas. Para ello nos servimos del concepto de metáfora cognitiva, que complementa al más conocido de metáfora literaria, mediante el análisis de la base conceptual que subyace a ambas, sin dejar de considerar la importancia fundamental del contexto cultural en que dichos documentos literarios han surgido ${ }^{3}$. Nuestra intención era conseguir una mejor comprensión de la forma en que los griegos conceptualizaban el sentimiento amoroso.

Recordemos que, siguiendo el esquema planteado por los pioneros en el estudio de las metáforas conceptuales, Lakoff y Johnson ${ }^{4}$, podemos dividir éstas en tres clases: (1) Metáforas orientacionales, en las que el hablante hace una valoración de elementos inmateriales, atribuyéndoles una determinada situación en un espacio imaginario; (2) metáforas ontológicas, mediante las que el hablante se refiere a elementos inmateriales por medio de la mención de sustancias tangibles cuya experiencia es indispensable para nuestra categorización y comprensión del mundo, y (3) metáforas estructurales, que, creadas sobre la base de los dos tipos anteriores, pero con una elaboración mucho mayor, permiten estructurar una actividad o una experiencia en términos de otra más concreta. Hemos de tener, asimismo, en cuenta la posibilidad de confluencia de varios esquemas conceptuales en una misma expresión metafórica, circunstancia para la que se ha acuñado el término de blending o amalgama ${ }^{5}$. Por lo demás, tendremos ocasión de documentar la motivación sinestésica de la metáfora, en casos en que la consideración de un sentimiento agradable se expresa mediante la alusión a una sensación física, así como la motivación metonímica en casos donde se expresan los síntomas del amor ${ }^{6}$.

No dejábamos de señalar, por una parte, la dificultad que se plantea en ocasiones para distinguir una metáfora cognitiva, asentada idiomáticamente, de una metáfora literaria, producto de la voluntad estética del autor, así como también somos conscientes de que la influencia de la lengua del epos en toda la literatura posterior puede llegar a tener un peso en la presencia de determinadas imágenes metafóricas prevalentes a lo largo de la historia de los textos griegos.

Por lo demás, las metáforas cognitivas referidas a los sentimientos y, en concreto, al amor, han sido profusamente estudiadas en lenguas como el inglés ${ }^{7}$, y sólo en fechas más recientes se ha emprendido su estudio para el griego clásico ${ }^{8}$.

\footnotetext{
Hualde (2016: 17-47).

Para la relación entre metáfora y cultura cf. Shore (1996), Kövecses (2005); recientemente en Macarthur (2012). Lakoff - Johnson (1986). Los estudios sobre metáfora y metonimia adquieren un gran vigor a partir de los años 90. Es imprescindible citar obras como Ruiz de Mendoza (1998: 259-274); MaccorMac (1985: 53-78), Steen Gibbs (1999) o Grady, Oakley, \& Coulson (1999); Fauconnier - Turner (1998: 133).

Una revisión reciente del desarrollo del estudio de la metáfora según las teorías contemporáneas en el volumen colectivo editado por Gonzálvez García (2013). Véase asimismo Gibbs (2008). Para la revisión del concepto de metáfora y alegoría a partir del mundo clásico cf. la recopilación de estudios en Boys-Stone, G.R. (2003).

$5 \quad$ Fauconnier - Turner (1998: 133); Ruiz de Mendoza (1998: 259-274); Grady, Oakley, \& Coulson (1999). Propuestas recientes de esta teoría en Schmid - Handl, (2011). Sobre el concepto de blending cf. asimismo Fauconnier - Turner (2002).

6 Los síntomas del amor son el amor en forma de metonimia, cf. Kövecses (1986:101); Kövecses (1990:52). También Santos Domínguez - Espinosa Elorza (1996:102).

7 Kövecses (1986, 1988, 1989, 1990); Barcelona Sánchez (1992), Beger - Jäkel (2009).

$8 \quad$ Pagán (2009, 2010, 2011), Hualde (2016), Cairns (2016).
} 
En cualquier caso, retomamos nuestro estudio analizando la presencia de estas metáforas amorosas en el ámbito de la tragedia griega y en una selección de textos helenísticos, para acabar con un cuadro de conclusiones generales.

\section{Metáforas de amor en la tragedia ateniense}

El ámbito de la tragedia podría resultar, en principio, menos proclive a la aparición de metáforas sobre el amor que el ámbito de la lírica, dado que el género dramático ateniense, vinculado al contexto democrático de la pólis, tiene en su naturaleza el debate, casi siempre en clave mítica, de asuntos públicos, de relevancia para la vida ciudadana. Aun así, la presencia de Eros y las referencias a la pasión amorosa existieron en la obra de los tres trágicos, en diversa medida y con claves distintas. De Esquilo no se nos ha conservado ninguna obra completa que presente el amor como elemento destacado $^{9}$, lo que avala que su producción debió de estar en general bastante desprovista de elemento erótico alguno -hasta el punto de que el personaje de Esquilo en Las Ranas de Aristófanes presume y se ufana de ello ${ }^{10}$ - aunque en algunos fragmentos de su trilogía Las Danaides y de la tragedia perdida Los Mirmidones, se puede colegir que existió de fondo el tema amoroso ${ }^{11}$. En la obra de Sófocles no está presente el amor romántico, como es esperable en autor tan mesurado a la hora de referirse a los humanos afectos, pero sí aparecen los dioses Eros y Afrodita, con especial relevancia en Las Traquinias y en algún punto de Antígona. Pero el autor que llevará a primer plano escénico un amor sexual impetuoso, al igual que otras pasiones violentas y desatadas, será Eurípides, como resultado del proceso de psicologización de los personajes que lleva a cabo en su obra, especialmente en los personajes femeninos como la Fedra de su Hipólito o la Medea de la tragedia del mismo nombre.

La presencia pues, de Eros, al menos en los dos trágicos más jóvenes nos permite seleccionar un corpus de textos en los que poder estudiar el funcionamiento de las metáforas amorosas, tanto en su base cognitiva, como en su expresión lingüística, ya corresponda ésta a una metáfora conceptual, asentada idiomáticamente, o a una metáfora literaria, fruto de la voluntad estilística del autor. Sin embargo, como ya vimos en el ámbito de la lírica, en ocasiones es difícil conseguir la delimitación entre ambos tipos de metáfora. A ello se añade que la tragedia resulta un contexto mucho más complejo a la hora de identificar y valorar las metáforas referidas al sentimiento amoroso, cualquiera que sea su naturaleza, sobre todo porque en la obra dramática los sentimientos eróticos están frecuentemente referidos a la acción directa de una divinidad, que realmente aparece como personaje de la obra. Esta dificultad puede salvarse, dado que se observa que en el drama se conceptualizan de la misma manera los sentimientos, sea el amor o el deseo (con minúscula), o Cipris (que no deja de ser

\footnotetext{
$9 \quad$ No obstante, las referencias a la sexualidad en Danaides, ha sido estudiadas por Zeitlin (1996) y Lévy, (1985). De especial interés por el uso de metáforas como referencia al cuerpo femenino Lisarrague, F. (1995:91-101).

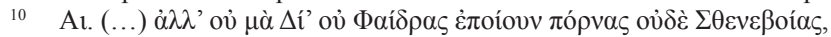

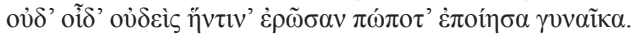

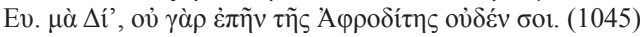

At. $\mu \eta \delta \varepsilon \gamma^{\prime} \dot{\varepsilon} \pi \varepsilon i ́ \eta \cdot(1045$, bis $)$

Esqu. (...)Pero, por Zeus, que no di vida en mi obra a putas como Fedra o Estenobea, ni nadie ha podido ver que pusiera yo en escena jamás a una mujer enamorada.

Eur. No, por Zeus, nada de lo de Afrodita iba contigo.

Esqu. Y que no vaya jamás.

11 Douterelo (1997: 196 n.2.).
} 
personificación de ambos) quien los provoque, por lo que tomaremos en el mismo sentido los datos de los textos trágicos seleccionados, procedentes de la obra de Sófocles y Eurípides. De Sófocles analizaremos, por una parte, el llamado Himno a Eros de Antígona (vs. 781-800) y Las Traquinias. De Eurípides Medea e Hipólito, que compararemos con algunas metáforas procedentes de los fragmentos de Andrómeda, obra que en la Antigüedad fue considerada amorosa por excelencia.

\section{Metáforas de amor en la obra de Sófocles}

\subsection{El Himno a Eros de la Antígona: alabanza al amor cósmico inevitable}

Un caso especial, dentro de la tragedia, lo constituye el llamado Himno a Eros que entona el coro de la Antígona de Sófocles entre los versos 781 y 800 de la tragedia. Este himno supone una alabanza al Eros cósmico, potencia universal inevitable. De manera que no es éste un amor romántico, sino más bien la fuerza que subyace en hechos positivos, como la sucesión de las generaciones de hombres y bestias, cuyo poder omnímodo es la base de las instituciones humanas. Por otra parte, esta fuerza del amor se considera en el pasaje sofocleo como causa de hechos negativos, caso de las guerras fratricidas y de las acciones injustas ${ }^{12}$. El texto, de trascendente contenido filosófico, ha sido estudiado en detalle ${ }^{13}$, y aquí sólo pretendemos determinar de qué manera parte del léxico que en él aparece se compagina con algunos de los esquemas conceptuales sobre el amor que hemos identificado en los textos griegos precedentes. Veamos el fragmento en su conjunto:

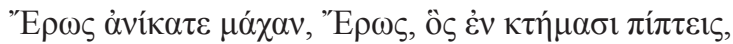

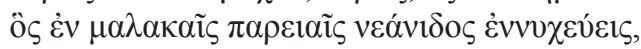

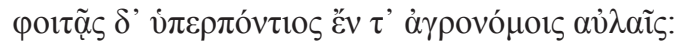

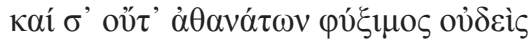

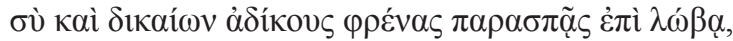

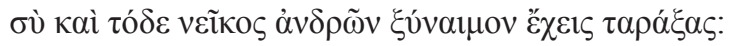

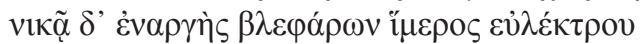

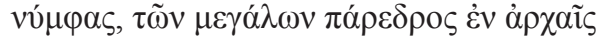

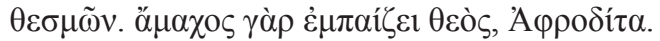

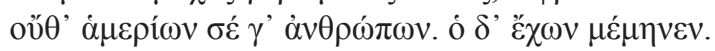
(781-800)

"Eros, invicto en el combate, Eros que te arrojas sobre nuestros animales, que haces las guardias nocturnas en las tiernas mejillas de la joven novia, que transitas por el mar y por las agrestes moradas. Nadie es capaz de evitarte, ni de entre los inmortales, ni de entre los efímeros hombres; el que te tiene queda enloquecido. Tú arrastras los sentidos de los hombres justos hacia las acciones injustas para su destrucción; tú, alterándolos, has conseguido esta disputa consanguínea entre los hombres; es evidente que vence el deseo de los párpados de la joven novia, el deseo que tiene su sede en los principios de las grandes instituciones: pues la divina Afordita, invencible, juguetea".

12 Sobre las dos caras del amor en los 17 versos del frag. 941 de Sófocles, el llamado Himno a Afrodita, cf. Pralon (1993: 125-131). También sobre el tema Saravia de Grossi (2007: 168-173).

13 Cf. Lasso de la Vega (1990: 55-79). 
Parece claro que el autor utiliza metáforas conceptuales, de carácter estructural, en cuatro ámbitos para referirse a Eros: EROS ES GUERRA, EROS ES MOVIMIENTO, EROS ES LOCURA Y EROS ES JUEGO. Se puede entrever una quinta metáfora, de carácter orientacional, pero sin connotaciones valorativas, que indicaría que EL AMOR EMANA DE LOS OJOS DEL AMADO ${ }^{14}$.

Dentro del ámbito conceptual EL AMOR ES GUERRA, básico para la representación de este afecto desde los primeros documentos literarios en lengua grie$\mathrm{ga}^{15}$, encontramos un Eros concebido como personificación del sentimiento que causa las discordias familiares, en clara alusión al conflicto acaecido entre Hemón

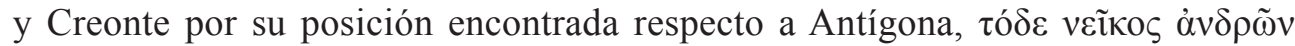

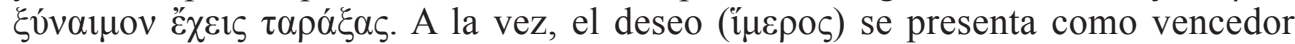

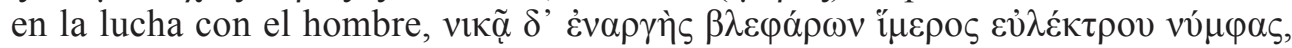
lucha en la que el hombre es derrotado sistemáticamente según las bases conceptuales de esta metáfora a lo largo de la literatura griega ${ }^{16}$. De especial interés son tres adjetivos que aparecen en el texto y que indican el fracaso a que está abocado

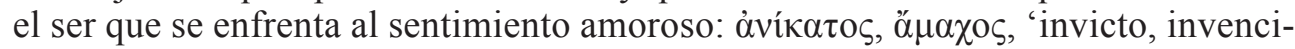

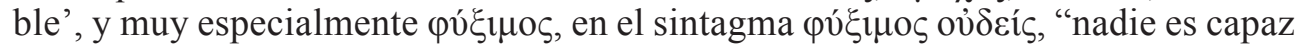

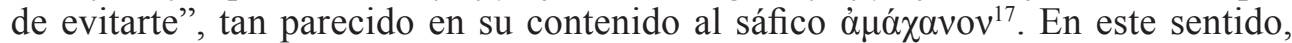

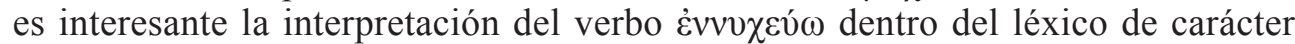
militar como 'hacer las guardias nocturnas' ${ }^{18}$, lo que convierte a la personificación literaria de Eros en un soldado, en consonancia con la base conceptual que subyace en todo el texto.

La metáfora que indica que EROS ES MOVIMIENTO se hace explícita en el verbo $\pi i \pi \tau \omega$, según el antiguo esquema cognitivo que entiende el amor y el deseo como elementos externos que caen sobre el hombre, y, en la concepción cósmica de Sófocles, también sobre los animales ${ }^{19}$. Por lo demás, la tradicional imagen del amor que altera las $\varphi \rho \varepsilon ́ v \varepsilon \varsigma$ humanas mediante el movimiento ${ }^{20}$ se reitera en $\varphi \rho \varepsilon ́ v \alpha \varsigma$

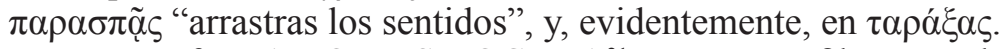

La metáfora AMOR ES LOCURA ${ }^{21}$, que se perfila ya en los poemas homéri$\cos ^{22}$ y que se desarrolla extraordinariamente en la poesía lírica arcaica, aparece en el himno sofocleo expresada de forma sucinta, pero rotunda como ó $\delta$ ' $̌ x \chi \omega v$

\footnotetext{
Para todas las metáforas de emisión remitiremos a los completísimos estudios de Pagán Cánovas (2010 y 2011). Hualde (2016: 23-24).

Hualde (2016: 41).

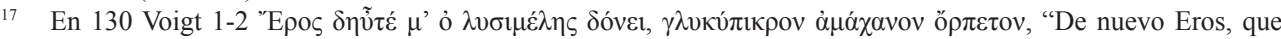
desata los miembros, me agita, dulceamarga sierpe contra la que es imposible luchar", cf. Hualde (2016: 37).

18 Saravia de Grossi (2007: 170), en consonancia con Brown (1997: 187, 784).

19 Cf. la nota 40 de la traducción de Antígona de Alamillo, en Biblioteca Clásica Gredos, (1981: 278), que sigue las

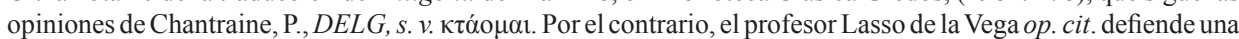

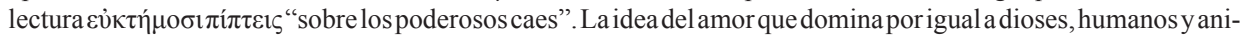

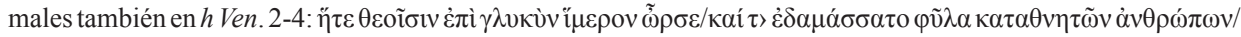

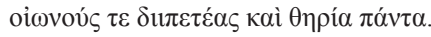

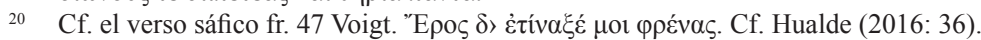

21 Sobre si la popular y recurrente imagen del amor como locura mantiene un rango especial dentro de la literatura griega, al margen del sentido metafórico aludido, cf. Dodds (1983) especialmente cap. III y Hualde (2016: 209).

22 Siempre que se entienda la locura como falta de juicio o razón. Así, bajo la expresión metafórica $\kappa \lambda \dot{\varepsilon} \pi \tau \varepsilon$ tv vóov

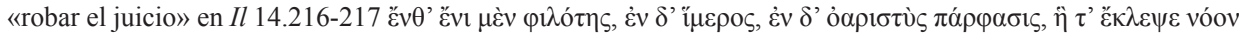

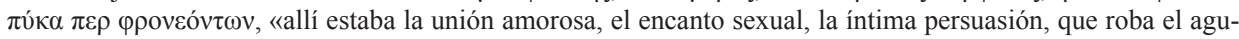
do juicio de los sensatos», aparece un blending o amalgama donde también puede observarse la metáfora EL AMOR Y LOS ELEMENTOS QUE LO ACOMPAÑAN SON LADRONES, cf. Hualde (2016:25).
} 
$\mu \varepsilon ́ \mu \eta v \varepsilon v^{23}$, "el que te posee queda enloquecido". Finalmente, resulta especialmente curioso que una imagen conceptual muy representativa del amor en otras lenguas, AMOR ES JUEGO, y que en la lírica griega aparece en un verso de Alcmán ${ }^{24} \mathrm{y}$ en dos de Anacreonte ${ }^{25}$, siempre en el marco de la metáfora literaria, casi de la alegoría, y haciendo referencia a la personificación de Eros-niño, aparezca aquí asociada a Afrodita, a quien el dios sistemáticamente acompaña, en $\gamma \grave{\alpha} \rho \dot{\varepsilon} \mu \pi \alpha i \zeta \varepsilon$ ct

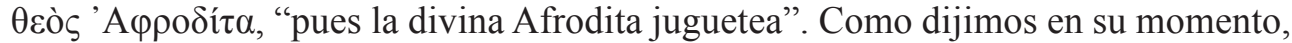
es posible que esta imagen se deba a la percepción humana de que su éxito amoroso está sujeto a los embates del azar26.

Nos hemos referido a una quinta metáfora como EL AMOR EMANA DE LOS

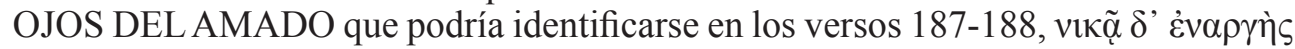

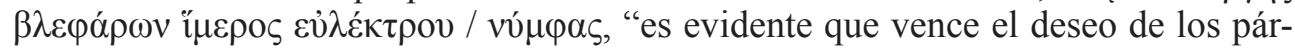
pados de la joven novia", siempre que entendamos que el genitivo $\beta \lambda \varepsilon \varphi \alpha ́ \rho \omega v$ que

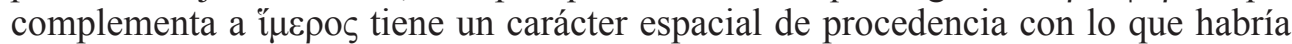
que traducir "el deseo procedente de los ojos". Esta imagen, podría ponerse en re-

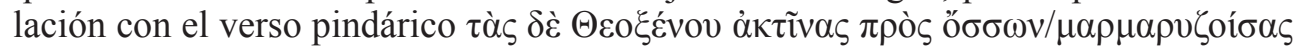

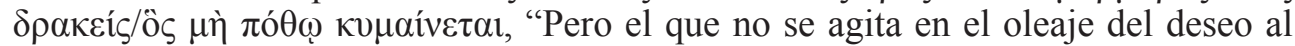
observar los resplandecientes destellos de los ojos de Teóxeno"27.

\subsection{Las Traquinias: Amor e ironía trágica}

Un papel más determinante tiene el amor en la obra sofoclea Las Traquinias, y no porque su autor se recree en la idea de un amor romántico, sino porque es la presencia de Yole, la joven esclava y concubina de Heracles la que motiva la decisión de Deyanira, la esposa legítima, de emplear la sustancia venenosa que antaño le diera el centauro Neso, en la firme convicción de que se trata de un filtro amoroso con el que reconquistar la atención erótica de su marido. El asunto pasional es secundario, pero necesario para explicitar el tema básico del drama sofocleo: el poder de los dioses ${ }^{28}$ frente a la ignorancia humana, lo que dará en esta obra algunos casos memorables de la conocida ironía trágica del autor.

En este estado de cosas, Sófocles hará uso mayoritariamente de metáforas amorosas cuya configuración y base cognitiva ya están establecidas en la épica y en la lírica arcaicas, como son AMOR ES LUCHA, EL AMOR PENETRA EN EL INTERIOR DEL HOMBRE, AMOR ES CALOR EXTREMO, AMOR HACE DERRETIR AL HOMBRE, AMOR ES MAGIA, y alguna de nuevo cuño, que triunfará en la dra-

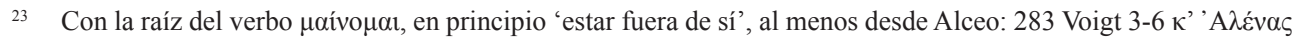

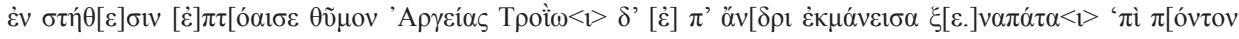
ह̌ $\sigma \pi \varepsilon \tau$ v väi, «Hizo dar un vuelco al corazón en el pecho de la argiva Helena, y, enloquecida, siguió al troyano engañador del huésped en su nave...».

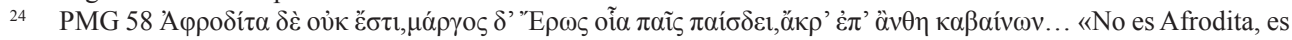
el loco amor, que, como niño, juega, subiendo hasta lo alto de las flores...».

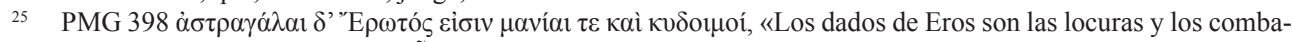

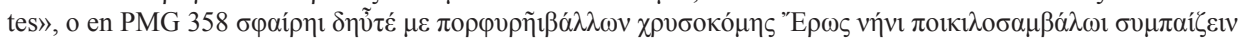
$\pi \rho о \kappa \alpha \lambda \varepsilon \tilde{\tau} \tau \alpha 1$, «Eros, de cabellos de oro, lanzándome de nuevo una pelota purpúrea me incita a jugar con él...»

26 Hualde (2016:40). Recordemos que esta metáfora estructural fue ya indentificada por Lakkoff y Johnson en 1980. Sobre la imagen de Eros jugando cf. Pretagostini (1990: 225-238).

27 Un estudio completo de la emisión erótica en la poesía griega, desde los puntos de vista cognitivo y semiótico aparece en Pagán (2009:210-215). A partir de este momento para la consideración de esta metáfora remitiremos a sus excelentes trabajos.

28 Morenilla (2013: 6). 
maturgia posterior como es AMOR ES ENFERMEDAD. No es baladí el hecho de que, salvo una, todas las metáforas empleadas se refieran a la pasión amorosa que siente Heracles por Yole y sólo una esté referida al amor de Deyanira por su esposo. Esto se compagina bien con la idea de que la acción de la princesa calidonia no esté motivada por el deseo erótico hacia su marido, sino al miedo de ser desplazada de la posición privilegiada que como esposa legítima tiene en el oikos por la presencia de la joven esclava de noble origen ${ }^{29}$. Sin embargo, la única imagen metafórica referida a la relación de Deyanira con su marido utiliza el término $\pi$ ó $\theta$ o ‘ 'añoranza, deseo añorante' y el verbo correspondiente $\pi$ oӨ́́o $\mu \alpha 1$ 'desear, echar de menos', y nos vemos obligados a decidir en la traducción si en este caso el término presenta matiz sexual o simplemente se refiere a el deseo de Deyanira de volver a ver a su esposo, sin

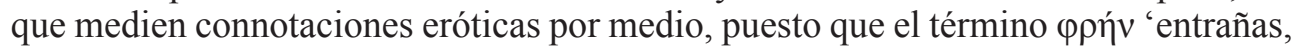
corazón, sede de los sentidos y sentimientos', no se refiere únicamente a emociones de carácter carnal $^{30}$. La metáfora, en realidad, supone una personificación de la añoranza o el deseo, EL DESEO ES UN SER VIVO, dado que en la imagen conceptual, ya atestiguada en Íbico de Regio, se le hace dormir ${ }^{31}$ para expresar el tiempo en que

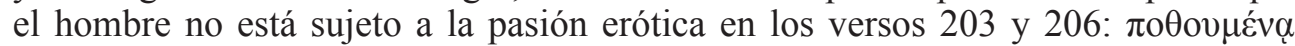

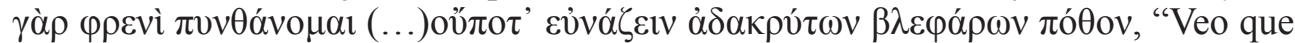
Deyanira (...) vive añorante en su corazón, y no puede dormir el deseo de sus ojos sin lágrimas...", texto en el que se ha identificado la imagen EL AMOR SE EMITE POR LA MIRADA ${ }^{32}$, también presente en los fragmentos 157, 1139, 474 del autor ${ }^{33}$.

Las metáforas amorosas que hacen alusión a los sentimientos de Heracles, por el contrario, no dejan lugar a dudas sobre el carácter erótico de los mismos, prevaleciendo aquella metáfora estructural que identifica el AMOR COMO LUCHA, en concreto una lucha mantenida entre el ser humano y el sentimiento amoroso, batalla que el hombre está destinado a perder de forma sistemática, según tenemos constancia desde los textos homéricos ${ }^{34}$. Ya en el verso 497 de la tragedia, Cipris, personi-

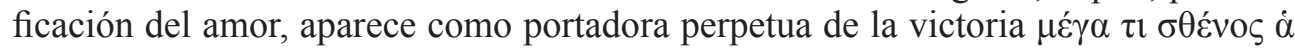

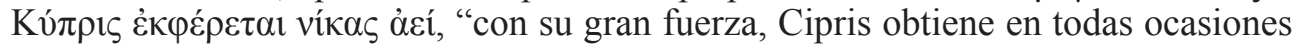
la victoria". Esta metáfora produce buen juego literario cuando se contraponen los triunfos físicos de Heracles, héroe famoso por su fuerza corporal, representada por sus manos, con su debilidad, como cualquier humano, ante la potestad de Eros en

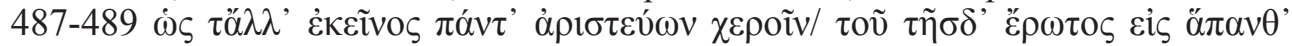

29 Morenilla (2013: 12).

30 Douterelo (1997:199), repara en que el empleo del verbo en voz media o voz pasiva parece propio del contexto amoroso en esta obra, mientras que los usos activos harían referencia a una añoranza de carácter más general.

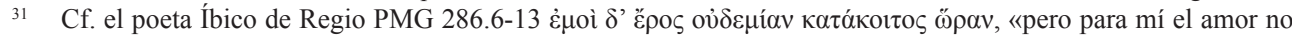
duerme en ninguna estación». Metáfora asimismo documentada en castellano, véase por ejemplo, El peregrino en su patria, de Lope de Vega (1604): "Prendió la Imaginación,/porque jamás descansaba,qque no hay locura

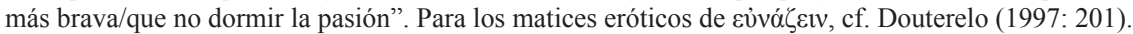

32 Como señala Douterelo (1997: 199) se trata de nuevo del tema del deseo que emana de los ojos, como también cabía interpretar los versos 187-188 de Antígona, cf. supra. No insistimos en esta imagen completamente estudiada por Pagán $(2009,2010$ y 2011).

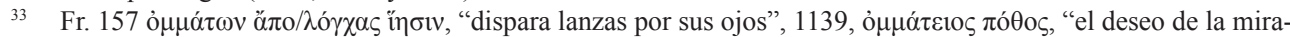

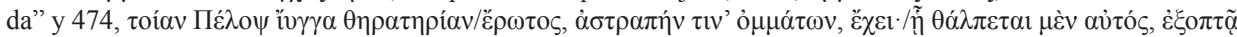
$\delta$ ' $\dot{\varepsilon} \mu \varepsilon$, "Pélope tiene tal hechizo para cazar el deseo, un fulgor en sus ojos con él que él mismo se inflama y a mí me abrasa". Este último fragmento tiene el innegable interés de presentar una amalgama entre varias metáforas como son AMOR ES CAZA, AMOR ES MAGIA, AMOR SE DESPIDE POR LOS OJOS y AMOR ES CALOR EXTREMO.

34 Cf. Hualde (2016:23). 


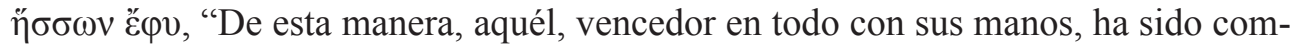
pletamente derrotado por el amor de ésta".

La lucha inútil y condenada al fracaso que el hombre se empeña en mantener con Eros ${ }^{35}$ cobra forma en el imaginario sofocleo mediante la imagen del pugilato amoroso, atestiguada cumplidamente en Anacreonte ${ }^{36}$, en la que la base cognitiva básica AMOR ES LUCHA sirve de fundamento para el desarrollo literario de la pro-

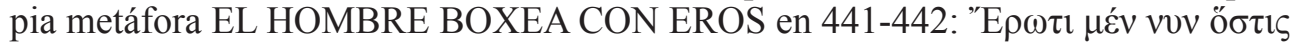

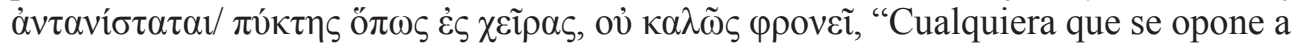
Eros, llegando a las manos como un boxeador, no está bien de la cabeza". ${ }^{37}$

Innegablemente, en la base de la tragedia sofoclea se halla la antigua concepción del amor como violencia externa sobre el ser humano. Desde Homero, esta violencia se sustancia en un impacto sobre el hombre o sobre su espíritu y que poco a poco va adquiriendo la imagen literaria de un dardo o una flecha ${ }^{38}$. En los textos más antiguos la idea de IMPACTO es frecuentemente compatible con la idea de EL HOMBRE ES UN RECIPIENTE/EL AMOR ES UNA CARGA, en forma de blending o amalgama, pero este es el primer caso que conozcamos en el que se consigna, mediante en la trayectoria de ese golpe inmaterial que es el "flechazo", que EL AMOR ATRAVIESA AL ENAMORADO DE PARTE A PARTE, mediante el empleo del verbo

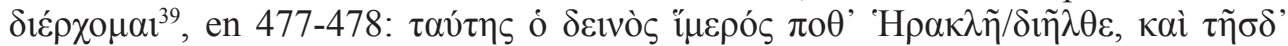

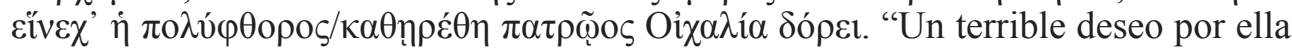
atravesó en otro tiempo a Heracles, y a causa de ésta fue destruida a punta de lanza la muy arruinada patria Ecalia".

Otra de las metáforas cognitivas básicas utilizadas en el imaginario griego para expresar la pasión amorosa es la metáfora ontológica EL AMOR ES CALOR EXTREMO, motivada metonímicamente ${ }^{40}$, conocida al menos desde el siglo VII $^{41}$ y empleada aquí por Sófocles para señalar la situación de Heracles, mediante el per-

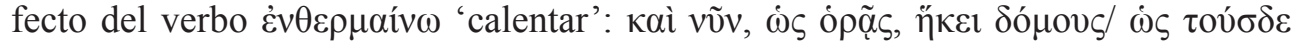

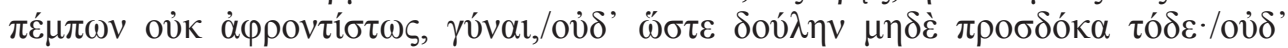

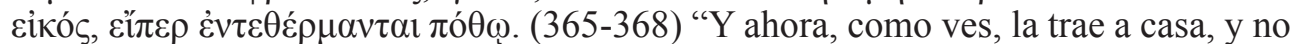
la trae sin intención, mujer, ni en calidad de esclava. No esperes esto, no es lo natural si está ardiente de deseo". El empleo de esta metáfora no parece arbitrario, ya que se ha puesto en relación con la muerte por abrasión que padecerá el héroe al final de la tragedia, lo que sería un claro testimonio de la ironía trágica sofoclea ${ }^{42}$. En cualquier caso, la consecuencia del calor en el mundo real es el derretimiento de algunas sustancias como la cera, referente que es utilizado por la metáfora EL AMOR DERRITE AL HOMBRE, en la cual no puede descartarse la alusión a los humores sexuales

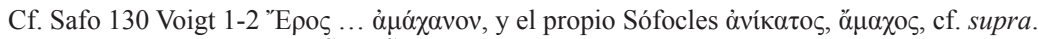

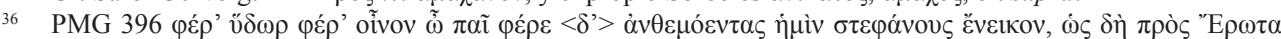
$\pi v \kappa \tau \alpha \lambda i \zeta \omega$, «Trae agua, trae vino, chico, traenos coronas floridas, que quiero boxear con Eros», y en PMG $346,4.1[\chi \alpha] \lambda \varepsilon \pi \tilde{\omega} \iota \delta \varepsilon \pi v \kappa \tau \alpha ́ \lambda ı \zeta .[$ «Contra el feroz (Eros) luchaba con mis puños»

37 La imagen aparece asimismo en un fragmento sofocleo $(941,13)$ referido a la diosa Afrodita, con quien Eros resulta frecuentemente intercambiable, cf. Douterelo (1997:198 n. 15).

38 Cf. Hualde (2016: 24-25, 44). Completísimo estudio en detalle Pagán (2011).

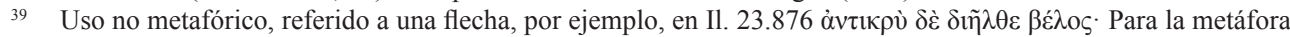
relacionada AMOR ES PROFUNDIDAD, atestiguada desde Arquíloco, cf. Hualde (2016:28).

40 Kövecses (1986:101), Kövecses (1990.52). También santos Domínguez - Espinosa Elorza (1996:102).

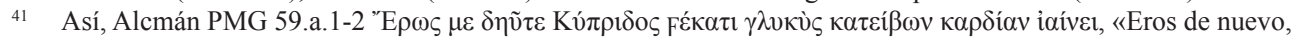
por voluntad de Cipris, inundándome, dulce, calienta mi corazón», cf. Hualde (2016: 31).

42 Kamerbeek (1959, ad locum.).
} 
que el deseo físico conlleva ${ }^{43}$. En el texto que nos ocupa, la metáfora va referida a

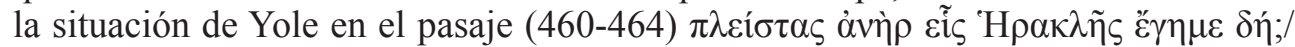

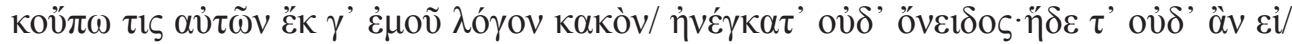

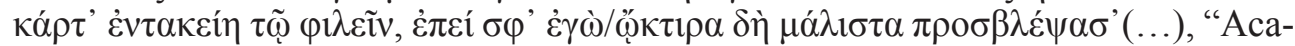
so Heracles, siendo un solo varón, no ha tenido muchas amantes? Y nunca salió de mí una mala palabra ni un reproche para ninguna de ellas. Y tampoco lo habrá para ésta, ni aunque esté por completo derretida de amor. Pues me compadezco mucho al verla....". Esta metáfora, completamente asentada en la lírica coral y monódica, siempre nos había aparecido asociada a los términos $\pi$ ó $\theta$ os (deseo añorante), o Épos, ह̌ $\rho \omega \varsigma$ (pasión sexual) y se daba en alusiones a un varón enamorado. Lo llama-

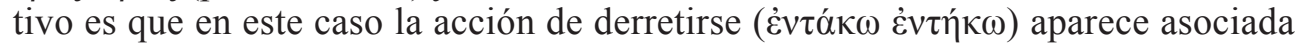

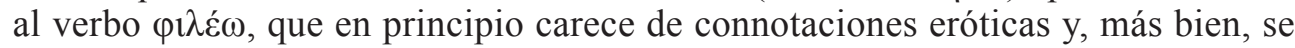
refiere al afecto entre amigos y dentro del grupo familiar. Por otra parte, este es el verbo que se utiliza para designar los sentimientos de correspondencia amorosa del eroménos, frente a los del erastés, que son expresados por formas de las raíces de $\pi$ ó $\theta$ o $\varsigma$ o ěpos, de carácter más netamente sexual ${ }^{44}$. Esto se compadecería bien con la situación planteada en la acción dramática, donde la iniciativa amorosa es evidentemente, de Heracles, que llega a destruir la ciudad de Ecalia con el fin de raptar a Yole, quien, a decir del texto euripideo, parece corresponderle en los sentimientos. Esto no implica que no se aluda de manera implícita a la pulsión erótica de Yole por su raptor, ya que estas connotaciones sexuales no se excluyen para el

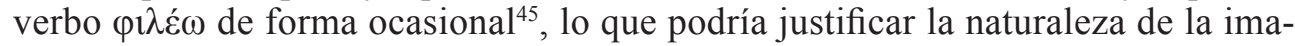
gen empleada.

Otras metáforas tradicionales como AMOR ES MAGIA, documentada desde los textos homéricos ${ }^{46}$, o AMOR ES LOCURA, ya utilizada por Sófocles en el Himno a Eros de su Antígona, constituyen tópicos literarios basados en la conciencia del hombre griego de encontrarse ante situaciones no controlables por el entendimiento humano. La primera de ellas, alude a las razones de Heracles para el saco de Ecalia,

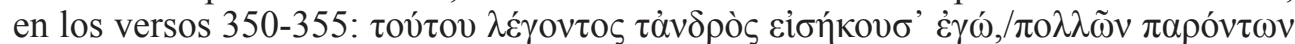

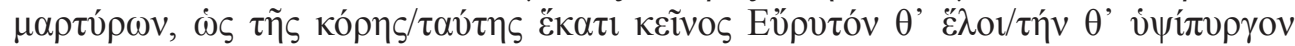

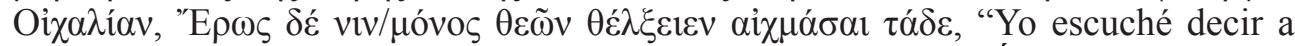
este hombre, y en presencia de muchos testigos, que él mató a Éurito y se apoderó de Ecalia de altas torres, por causa de ésta, y que únicamente Eros de entre los dioses le hechizó para emprender esta lucha". La segunda metáfora, que identifica el deseo con la locura y que ya empleaba el autor en su Himno a Eros, aparece en este

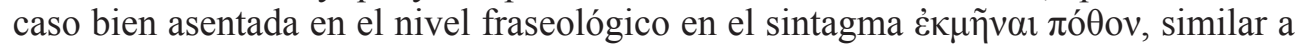

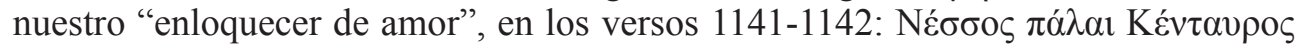

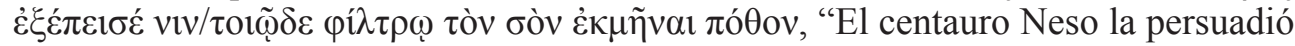
en otro tiempo de que con este filtro (Heracles) enloquecería de amor".

43 Cf. Hualde (2016: 31, 34, 41).

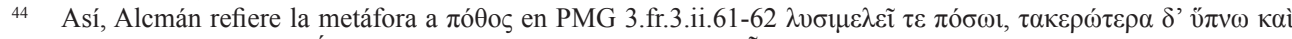

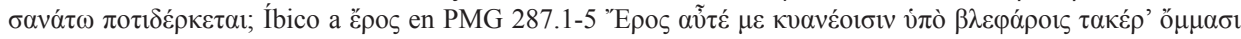

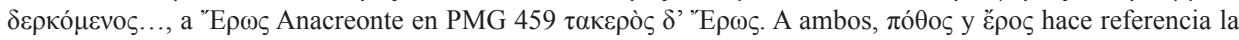
metáfora de Píndaro, documentada en el Elogio de Teóxeno, Cf. Hualde (2016).

45 Cf. Adrados (1995: 31). Sobre la dificultad sintáctica que permitiría interpretar que es Heracles el sujeto de $\varphi$ ı $\varepsilon \tilde{\mathrm{i} v}$, cf. Douterelo (1997: 202).

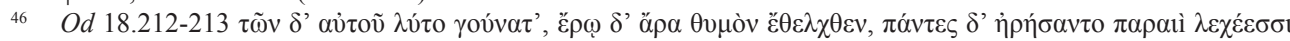
$\kappa \lambda \imath \theta \tilde{\eta} v \alpha 1$, «y a ellos al punto se les aflojaron las rodillas y su corazón era hechizado por el deseo y todos desearon acostarse junto a ella en el lecho...» Cf. Hualde (2016:25). 
No obstante, la novedad metafórica de este autor estriba en la imagen AMOR ES ENFERMEDAD, que consagrará poco después Eurípides en su Hipólito, en el año 428 , siempre que nos unamos a la opinión mayoritaria acerca de la representación temprana de Traquinias, entre los años 450-440. La metáfora se documenta en dos pasajes que aluden a la pasión de Heracles por Yole, y aparecen en boca de Deyanira con el fin de aminorar la culpa del desvío emocional de su esposo. Así en 445-446:

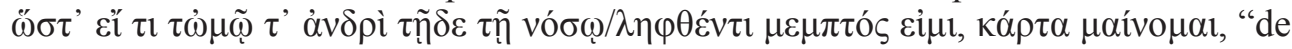
forma que muy loca estoy si hago reproches a mi marido, que está atrapado por

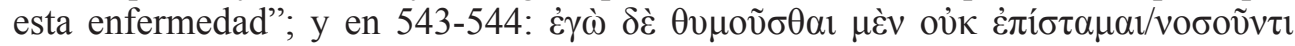
$\kappa \varepsilon i ́ v \omega \pi \mathrm{o} \lambda \lambda \dot{\alpha} \tau \tilde{n} \delta \varepsilon \tau \tilde{n}$ vó $\sigma \omega$, "Yo no soy capaz de enfadarme con él, porque está muy afectado por esta enfermedad". Por lo demás, de nuevo el empleo de esta metáfora novedosa no sería arbitrario, sino que vendría determinada por la técnica de la llamada ironía trágica, ya que en la parte final del drama será una enfermedad real la que aqueje al personaje de Heracles y la que, en definitiva, determine su muerte.

\section{Eurípides: Hipólito y Medea}

Es Eurípides el gran innovador del mito en la escena, el autor que fue capaz de despojar a héroes y heroínas de la semnótes tradicional y de hacer de ellos el espejo de los humanos, arrastrados por sus pasiones, que el ilustrado ateniense diseccionará de forma casi psicoanalítica. Será Eurípides el primero en llevar a escena la pasión erótica descarnada, tema importante en su obra y que aborda con gran penetración psicológica. Las dos tragedias en que este sentimiento es tratado con especial interés son Hipólito y Medea, así como parece que fue el caso de la Andrómeda, de la que sólo se conservan fragmentos. Por ello, van a ser objeto de nuestro análisis.

\subsection{Hipólito: el amor que lastima}

Es Hipólito el drama griego en el que se expresa más desnudo el sentimiento amoroso. El propio tema mítico, creado sobre el motivo denominado "Historia de Putifar", propicia la aparición de asuntos tan escabrosos como la pasión prohibida, el adulterio y el incesto. Tanto es así que, como es bien sabido, una primera tragedia perdida de Eurípides sobre el tema, conocida como Hipólito velado, constituyó un rotundo fracaso en el momento de su representación (432 a.C.), debido al escándalo que supuso la aparición en escena de una Fedra que confesaba personalmente su amor a su hijastro. La tragedia conservada, Hipólito portador de la corona o, sencillamente, Hipólito, es la versión del mito que el trágico puso en escena cuatro años más tarde del fracaso original y en el que la confesión de la funesta pasión de la cretense no se hace de forma personal, sino por medio de la figura de la nodriza. Las reflexiones de Fedra ante su incontrolado sentimiento proporcionan a lo largo de la tragedia un material abundante sobre la conceptualización metafórica del amor en la literatura griega.

Si hay una imagen predominante sobre el amor que pueda deducirse de las palabras del personaje femenino de la obra es que el amor es algo perjudicial y dañino, con un evidente componente de violencia. Así la metáfora estructural EL AMOR ES DAÑO/ DOLOR/ PERJUICIO, tiende a conceptualizarse de forma más concreta, en las metáforas ontológicas EL AMOR ES UN GOLPE, en $38 \kappa \alpha ̉ \kappa \pi \varepsilon \pi \lambda \eta \gamma \mu \varepsilon \dot{v} \eta$

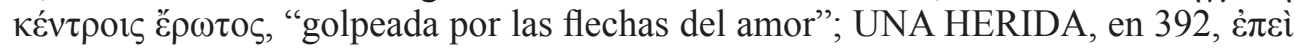




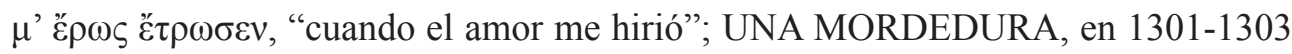

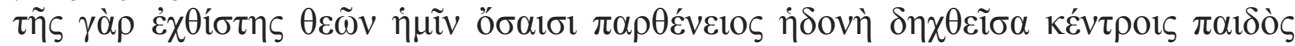

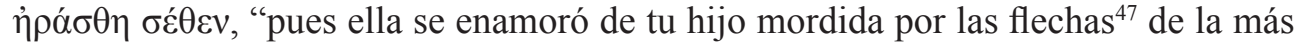
odiada de las diosas para nosostras, cuantas tenemos un virginal placer..."; UNA

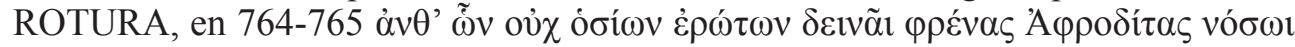
$\kappa \alpha \tau \varepsilon \kappa \lambda \alpha ́ \sigma \theta \eta$, "por eso, la terrible enfermedad de unos amores impuros, enviada por Afrodita, le rompió por completo el corazón" o, definitivamente, LA MUERTE, en

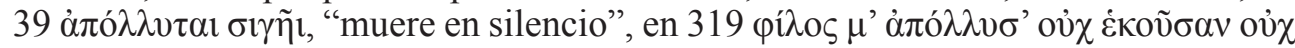

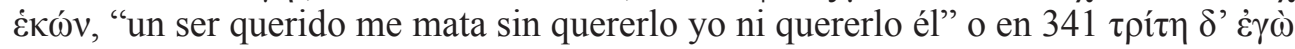

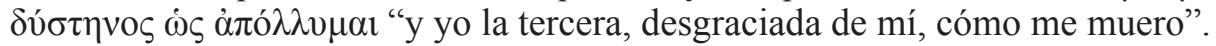

La consideración negativa y agresiva del sentimiento erótico se complementa mediante una sinestesia bien conocida que supone que EL AMOR ES SABOREA-

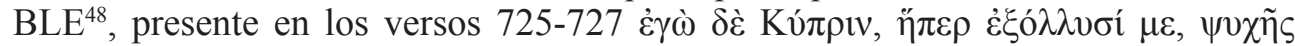

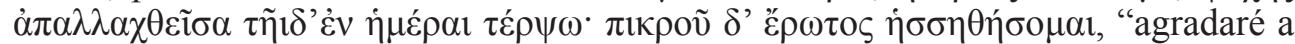
Cipris que me destruye abandonando hoy la vida. Un amor amargo me va a derrotar", donde aparece amalgamada con la consabida metáfora EL AMOR ES GUE-

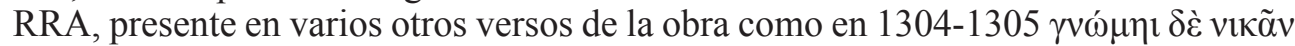

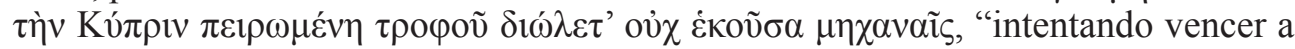
Cipris, sin querer, murió por los manejos de la nodriza".

La propia estimación del amor como una circunstancia perjudicial para la persona que lo experimenta desemboca en la muy productiva metáfora AMOR ES ENFERMEDAD, recurrente a lo largo de la obra y que supone una innovación atribuida a Eurípides ${ }^{49}$, aunque, como hemos observado supra, ya la utiliza Sófocles en sus Tra-

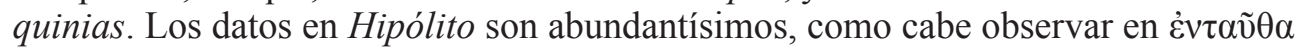

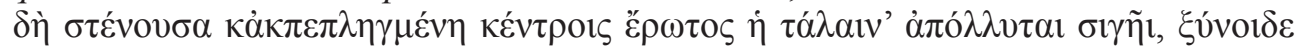

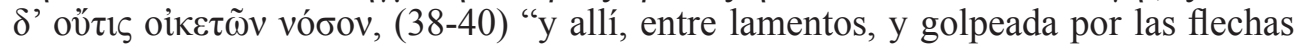
del amor la desgraciada muere en silencio y ninguno de sus sirvientes conoce su

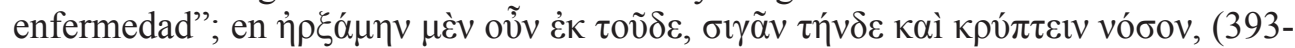
394 ) "a partir de este momento empecé a callarlo y a ocultar mi enfermedad"; en tò

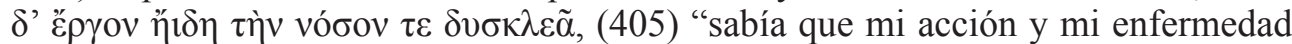

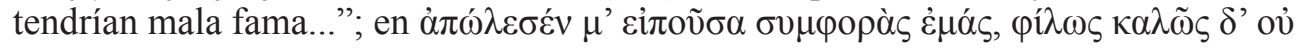
$\tau \eta ́ v \delta$ ' i $\omega \mu \varepsilon^{\prime} \eta \eta$ vóбov, (596-597) "me ha destruido con contar mi desgracia, al tratar de

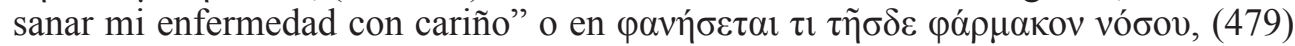
"aparecerá algún remedio para tu enfermedad".

Las consecuencias de tal enfermedad se concretan mediante la metáfora EL AMOR DESGASTA como aparece, con distinto lexema en cada caso ( $\tau \rho v ́ \chi \omega, \tau \varepsilon i ́ p \omega)$,

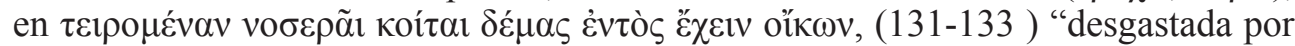
la enfermedad reposa su cuerpo en el lecho dentro de la casa...", o en †бù $\delta$ '† ả $\mu \varphi \grave{~}$

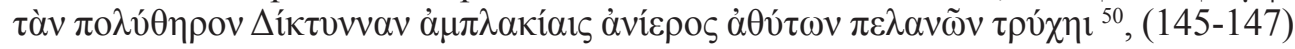

47 La expresión metafórica EL AMOR CONTRARIADO / EL DOLOR QUE ELLO PROVOCA MUERDEN aparece en la poesía española "y así cuando se desdiga/de lo que me dijo entonces/no me morderá el dolor/de haber perdido una dicha/ que yo tuve entre mis brazos/ igual que se tiene un cuerpo", Pedro Salinas, La voz a ti debida.

48 Documentada al menos desde el Himno a Afrodita y está presente en Alcmán, Safo y Teognis, cf. Hualde (2016).

49 Recordemos que un estudio del amor como enfermedad en esta obra, intentando ver en su descripción y síntomas ecos de la medicina hipocrática en Márquez Guerrero (2004:43-63) y Cabello Pino (2006). Para el tópico en época helenística cf. Cabello Pino (2012: 38-57).

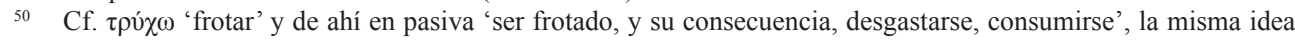
aparece en $\tau \varepsilon i ́ p \omega$. 
“¿, impía, te consumes por la falta de sacrificios a la diosa Dictina protectora de las fieras?".

La infausta pasión es descrita en términos de retención, por medio de la metáfora,

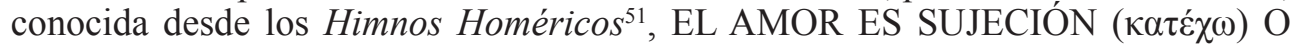

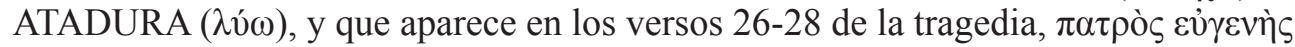

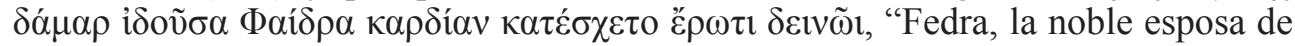
su padre, al verlo, sintió completamente sujeto su corazón por un terrible amor...", a lo que se opone la opinión utópica de la nodriza sobre la necesidad de poder des-

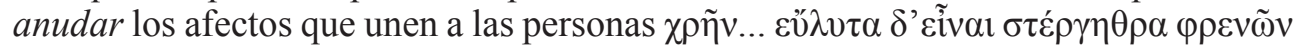
"deberían ser fáciles de desligar los afectos del corazón..."

La sobradamente conocida imagen AMOR ES LOCURA, aparece bien como tal, bien mediante las metáforas secundarias que explican que LA LOCURA ES UNA

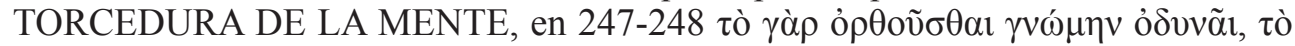

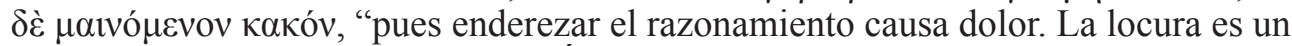

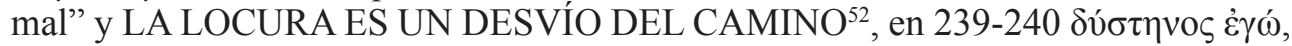

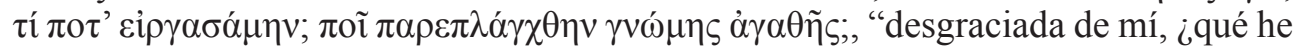
hecho? ¿por dónde me aparté del camino del buen razonamiento?” o en 282-283 бv̀

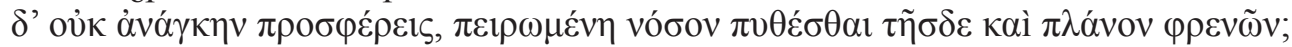
"y tú ¿no la puedes obligar, intentando informarte de su enfermedad y de sus prontos de locura?", entendiendo que etimológicamente $\pi \lambda \alpha v^{\prime} \nu v^{53} \varphi \rho \varepsilon v \tilde{\omega} v$ significa "el extravío de su mente".

Por otra parte, vuelve a aparecer la base conceptual, conocida desde los poemas homéricos, que supone que el hombre ES UN RECIPIENTE EN EL QUE SE CONTIENEN Y SE TRANSPORTAN LOS SENTIMIENTOS, en necesaria amalgama con la metáfora de emisión, que supone que el amor es un elemento que cae sobre el ser humano ${ }^{54}$. Claramente se recoge dicha imagen en la expresión metafórica que conceptualiza EL AMOR ES UNA CARGA, en amalgama con el consabido EL

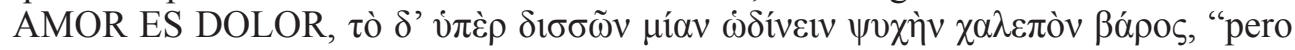
que un alma sufra violentos dolores por dos es una carga difícil de llevar". Sin embargo, no sólo es pertinente la idea de contenedor, sino la de profundidad, ya que EL AMOR SE SITÚA EN LA PARTE MÁS INTERNA DEL SER HUMANO, siguiendo el esquema conceptual AMOR ES PROFUNDIDAD, tal como aparece en boca

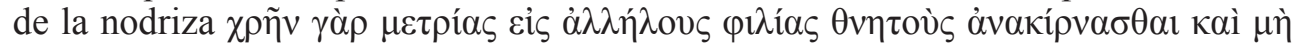

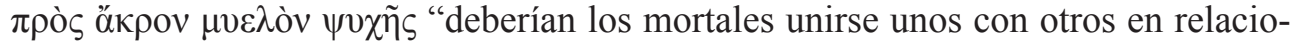
nes moderadas, que no llegasen a lo más profundo de la médula del alma"55, lo que conlleva a su vez la consideración del principio vital inmaterial como una estructura corporal, EL ALMA ES UN CUERPO.

Por otra parte, en los textos euripideos se ha producido una lexicalización para la expresión de la imagen de recipiente por medio del empleo de formas de $\varphi \varepsilon ́ p \omega$

51 Cf. Hualde (2016: 23). En el Himno a Afrodita para la expresión de esta metáfora se utiliza la raíz verbal *selpresente en el aoristo $\varepsilon \tilde{i} \lambda \mathrm{ov}$.

52 Cf. latín delirare.

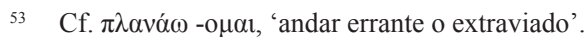

54 Cf. Hualde (2016: 24). Pagán (2009, 2010 y 2011).

55 La metáfora AMOR ES PROFUNDIDAD EN EL SER HUMANO, representada por la mención a los huesos

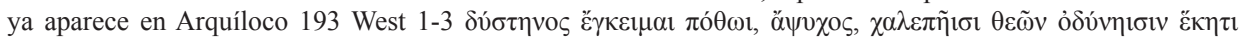

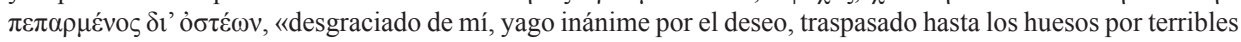
dolores por voluntad de los dioses». Cf. Hualde (2016:28) 
y sus compuestos que, sobre la misma base conceptual, resultan expresiones metafóricas similares a nuestro "soportar" o "sobrellevar". Así se puede ver en 391-393

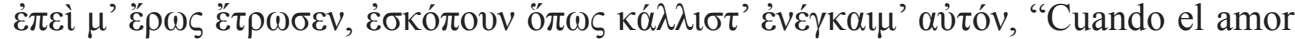

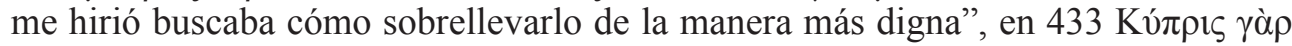

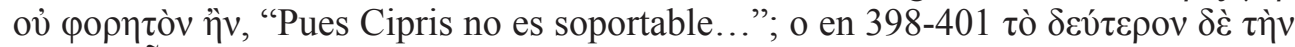

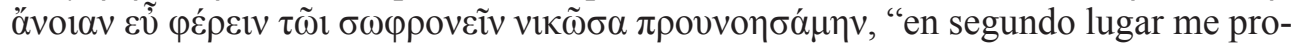
puse soportar bien la sinrazón venciéndola con la sensatez".

Por lo demás, la metáfora IMPACTO/RECIPIENTE, que supone que el amor

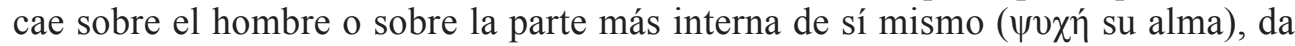
lugar a expresiones metafóricas más concretas, cuyo carácter conceptual, es decir, de expresión asumida en la fraseología del idioma, o literario, esto es, buscado por la voluntad de originalidad del autor, resulta impreciso. Es el caso de las imágenes que suponen que EL SER HUMANO ES UN CAMPO / EL AMOR ES UNA SE-

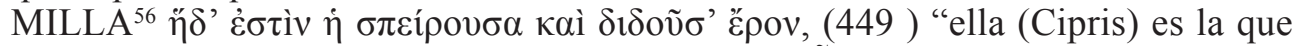

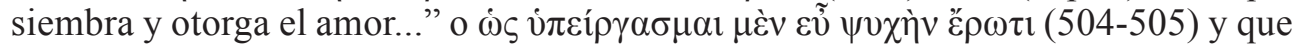
podríamos traducir, adaptándola a la fraseología castellana, por "qué profundamente ha calado en mi alma el amor", a partir de un literal "bien profundamente ha sido labrada mi alma por el amor" donde subyace que EL AMOR ES UN ARADO/ EL ALMA ES TIERRA.

Curiosamente, sin embargo, existe una metáfora alternativa o complementaria, según la cual es el amor el que se conceptualiza como un recipiente, externo al hombre, y es el hombre el que cae en el amor, según el esquema LA DESGRACIA AMOROSA ES UN ABISMO EN EL QUE EL HOMBRE SE SUMERJE, SUPERAR

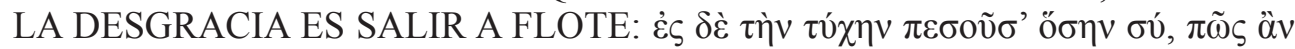

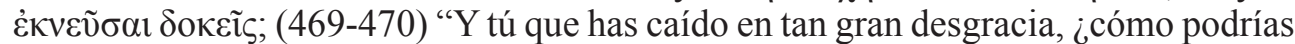
salir a flote?", donde volvemos a ver la metáfora orientacional y valorativa ABAJO ES MALO / ARRIBA ES BUENO. Esta conceptualización del sentimiento amoroso, aunque menos frecuente que la que hace del hombre un recipiente del sentimiento, ya la encontramos documentada en Anacreonte ${ }^{57}$ y la utilizará explícitamente el propio

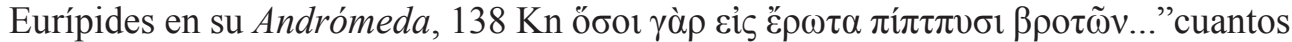
de los hombres caen en el amor..." ${ }^{58}$, base cognitiva y expresión metafórica coincidentes con el inglés "fall in love", e, incluso con nuestro "enamorarse".

La representación del sentimiento mediante la metáfora ELAMOR ES UN FLUIDO ( $\sigma \tau \alpha ́ \zeta \omega, \rho \in \varepsilon ́ \omega)$ tampoco escapa a la expresión de Eurípides en varias ocasiones. En amalgama con la imagen habitual EL AMOR ES GUERRA y, sobre todo, como metáfora de emisión del amor a partir de la vista ${ }^{59}$ se documenta en "E $\rho \omega \varsigma$ "E $\rho \omega \varsigma$,

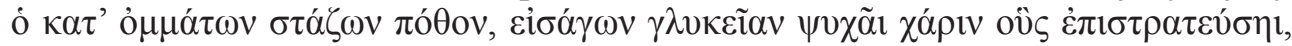

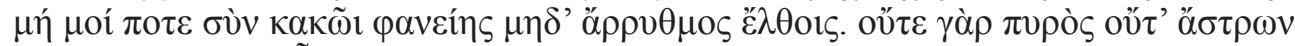

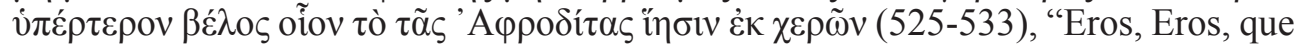

56 Ya subyace la misma base conceptual en la imagen literaria del Corpus Theognideum, Eleg. 2.1277-1278

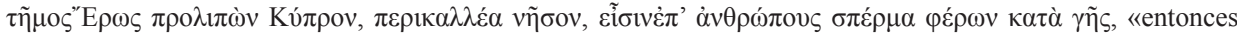
Eros, habiendo dejado atrás la muy hermosa isla de Chipre, va por toda la tierra llevando su semilla a los hombres», cf. Hualde (2016: 29).

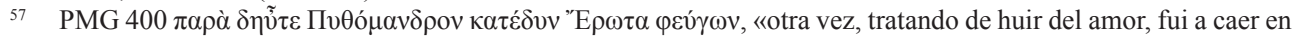
Pitomandro», donde subyace la metáfora AMAR ES SUMERGIRSE. Cf. Hualde (2016:40).

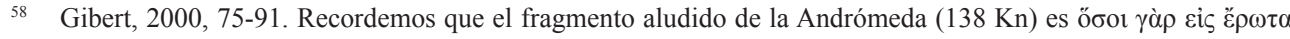

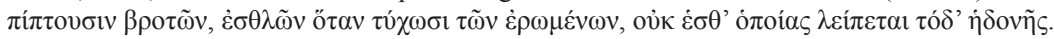

59 Ya presente en la tragedia en Sófocles, Antígona, Traquinias y diversos fragmentos, cf. supra y Douterelo, (1997: 199) y Pagán $(2009,2010,2011)$. 
haces manar deseo de tus ojos, infundiendo un dulce placer en el alma a aquellos a los que atacas, que nunca te me muestres junto con un mal, ni llegues desacompasado. Pues ni la flecha de fuego ni la de los astros es más poderosa que la que se lanza de las manos de Afrodita". La misma base conceptual en amalgama con la tradicional metáfora estructural EL AMOR ES POSESIÓN $(\lambda \alpha \beta o \tilde{\sigma} \sigma)$ aparece en

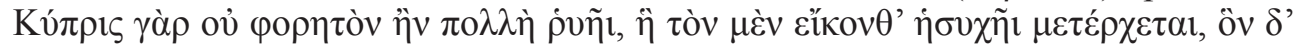

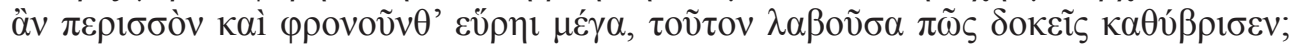
(443-446) "Pues si Cipris fluye en exceso no es soportable. Al que la acepta de buen grado proporciona la calma, pero al que encuentre soberbio o altivo, tomándolo (prisionero) ¿qué te parece? lo maltrata...", con el fin de expresar la ya aludida utopía euripidea del "amor con mesura". Este ideal irrealizable aparece también expresado mediante las metáforas orientacionales (EL AMOR SE PUEDE EMPUJAR, DESPLAZAR (ڤ̋ $\sigma \alpha \sigma \theta \alpha \imath) /$ EL AMOR SE PUEDE CONTENER ( $\xi v v \tau \varepsilon i v \alpha \imath)$, indicando la posibilidad de control del sentimiento por parte del hombre, en estos versos casi

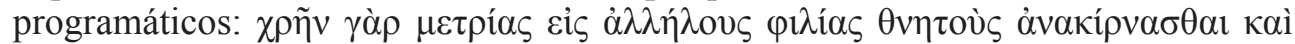

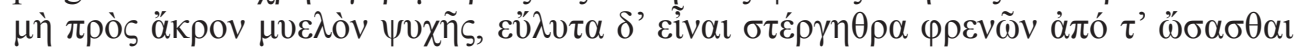

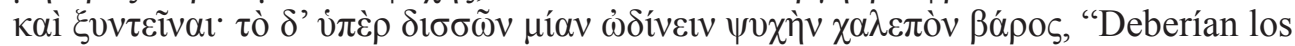
mortales unirse unos con otros en relaciones moderadas, que no llegasen a lo más profundo de la médula del alma, y que fueran fáciles de desanudar los afectos del corazón, tanto si se trata de arrancarlos como si se trata de mantenerlos a raya. Pero que un alma sufra violentos dolores por dos es una carga difícil de llevar".

Dentro del ámbito de la expresión amorosa resulta especialmente curiosa la lexicalización una primitiva metáfora ontológica EL AMOR Y EL SUFRIMIENTO QUE PRODUCE SON TEMPORALES O TORMENTAS ${ }^{60}$, cuya base conceptual ya aparecía en la imagen literaria presente en un texto teognídeo ${ }^{61}$. Se trata del verbo $\chi \varepsilon 1 \mu \alpha ́ \zeta o \mu \alpha 1$, que de "verse inmerso en una tormenta o temporal", pasa a

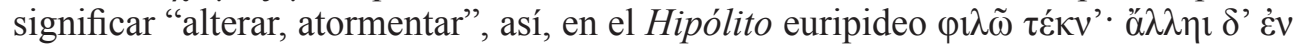
$\tau u ́ \chi \eta ı ~ \chi \varepsilon 1 \mu \alpha ́ \zeta \zeta o \mu \alpha 1,(315)$, "Quiero a mis hijos, pero estoy metida en otra tormenta del azar...".

Entre la metáfora conceptual y la metáfora literaria o la personificación se encuentra la imagen EL AMOR SOPLA / EL AMOR VUELA, que aparece en: $\delta \varepsilon \imath v \grave{~}$

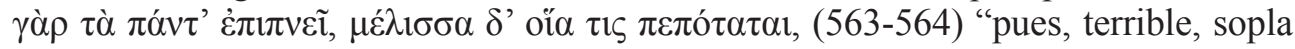
por todas partes y como una abeja revolotea", pues, aunque el sentimiento es susceptible de conceptualizarse en forma de un soplo de aire, como imagen más concreta de la metáfora EL AMOR ES MOVIMIENTO, a ello se une la imagen tradicional de Eros como genio alado ${ }^{62}$, bajo la que, en cualquier caso, subyace la propia idea de impulso y dinamismo, que sí aparece explícita en otros versos de la tragedia, en los que se consigna que el movimiento está destinado a los sentidos ( $\varphi \rho \varepsilon ́ v \varepsilon \varsigma)$ o

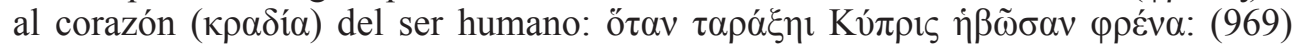
"Cuando Cipris agita sus sentidos (sc. los de un hombre) en plena juventud...", $\sigma \grave{~}$

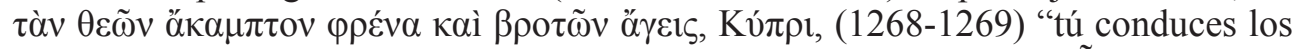

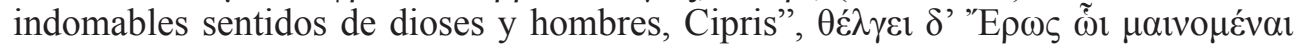

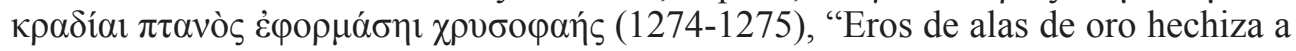

\footnotetext{
60 Para la metáfora literaria de la tormenta cf. Spatafora (2003:567-591).

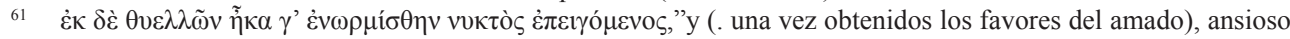
en la noche amarré lejos de las tormentas" Hualde (2016:29).

62 De nuevo imprescindible el magnífico estudio de Pagán (2011).
} 
aquel cuyo enloquecido corazón impulsa...”, expresión metafórica esta última que amalgama las consabidas metáforas EL AMOR ES MOVIMIENTO, EL AMOR ES LOCURA y la sólo documentada hasta este momento en Homero, en Íbico ${ }^{63}$ y en Sófocles El AMOR ES MAGIA.

Intencionadamente hemos dejado para el final el lamento de Fedra del verso

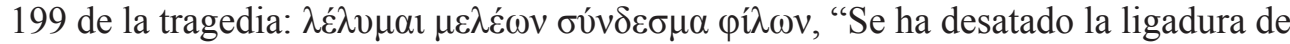
mis miembros". Creemos que el hecho de que esta queja se produzca inmediatamente después de las especulaciones del coro acerca de la enfermedad de la reina y de que sean prácticamente las primeras palabras que ésta pronuncia en escena no es un hecho baladí. Por el contrario, nos parece que con esta frase el personaje está aludiendo, en clave, desde el primer momento de su intervención, a la situación en que se encuentra, malinterpretada al pie de la letra como enfermedad física por el coro

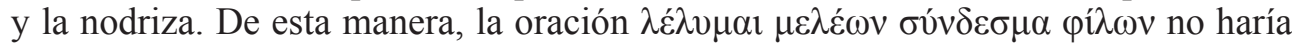
más que expresar de forma analítica el contenido del adjetivo $\lambda v \sigma \mu \varepsilon \lambda \eta ́$ s, que desde Hesíodo y pasando por Arquíloco y Safo está asociado al amor y al deseo, y Fedra vendría a querer decir algo equivalente a "estoy completamente enamorada". Así, el público espectador, al menos el que conociera bien la épica y la lírica, tendría la clave de la situación desde el comienzo de la obra, mientras que el coro y los personajes permanecerían ignorantes, acrecentando la intriga tan propia de la tragedia del autor ateniense. Por lo que al carácter metafórico de la expresión respecta, recordemos una vez más, que, en los términos que nos movemos, los síntomas de una emoción son una metonimia de la emoción misma ${ }^{64}$, luego EL AMOR ES DEBILIDAD EN LAS ARTICULACIONES.

\subsection{Medea: el lecho que posee al hombre}

Tal vez pocos textos son tan pertinentes para hablar de la metáfora y la metonimia como la Medea de Eurípides, obra que trata sobre el desamor, la deslealtad, la humillación y los celos. Desde que se emprende la lectura se puede detectar que toda la

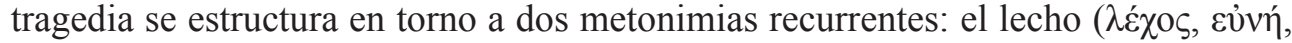

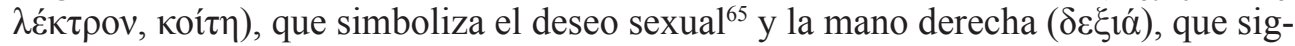
nifica la lealtad ${ }^{66} \mathrm{y}$ la fidelidad, a la que Jasón ha faltado.

Sobre la primera de ellas, mención del lecho por el sentimiento erótico que lleva a él a los amantes, nos compete tratar aquí, ya que va a presentar los mismos esquemas metafóricos que los ya vistos para el amor y el deseo en los textos precedentes. Así, esta metonimia funciona en expresiones que indican que EL HOMBRE SE ENAMORA DEL LECHO, es decir, del atractivo sexual de una mujer દi $\gamma \hat{\alpha} \rho \tilde{\eta} \sigma \theta$ ',

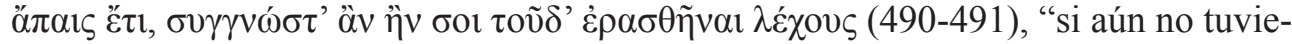
ras hijos, sería perdonable que te hubieras enamorado de ese lecho", e incluso hace explícita la metáfora conceptual EL AMOR ES POSESIÓN, mediante el desarrollo de la idea de que EL LECHO POSEE AL HOMBRE, caso de Jasón, seducido por el

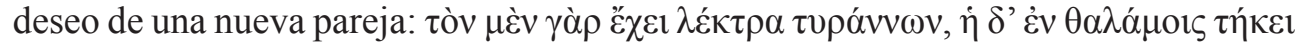
$\beta$ ßot̀ेv (140-141) "pues a él le posee un lecho de la realeza, mientras ella consume

\footnotetext{
En Od. 18. 212-213 e Ib. PMG 287. 1-5. Cf. Hualde (2016: 25 y 31).

Kövecses (1986:101); Kövecses (1990:52). También Santos Domínguez - Espinosa Elorza (1996:102).

Imprescindible el excelente estudio sobre los celos y el deseo sexual en Sanders (2013: 41-58).

66 Flory (1978:69-74).
} 
su vida en su habitación matrimonial". La misma metonimia se documenta para explicitar la metáfora LAS RELACIONES ERÓTICAS SON UNA LUCHA (en este caso, con una mujer rival) en la expresión $\sigma \tilde{\omega} \nu \tau \varepsilon \lambda \varepsilon_{\varepsilon} \kappa \tau \rho \omega \nu$ ŏ $\lambda \lambda \dot{\alpha} \beta \alpha \sigma i ́ \lambda \varepsilon 1 \alpha \kappa \rho \varepsilon i ́ \sigma \sigma \omega v$

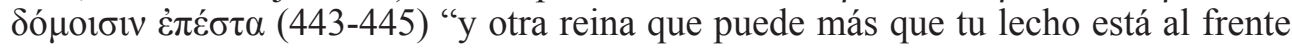
del palacio...". También la imagen del lecho sirve para manifestar la metáfora LOS CELOS LASTIMAN en la expresión, que también hay que leer en términos metafóricos, EL (ABANDONO DEL) LECHO PRODUCE UNA ESCOCEDURA ở $\chi$,

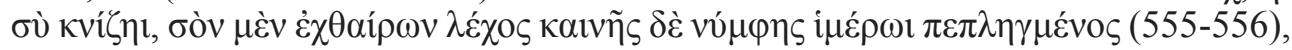
"no (he aceptado la boda) por lo que a ti te escuece, porque haya aborrecido tu lecho

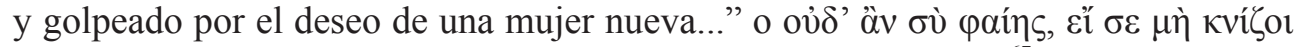
$\lambda \varepsilon ́ \chi 0 \varsigma$ (568) "tú no podrías decirlo, si no te escociera tu lecho..." . ${ }^{67}$.

Por lo demás, aparecen las expresiones metafóricas bien asentadas para concretar la concepción de que EL AMOR ES UN MAL / EL AMOR HACE DAÑO, como

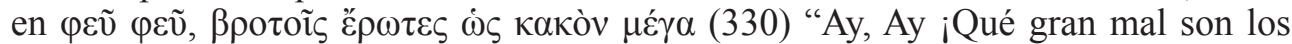

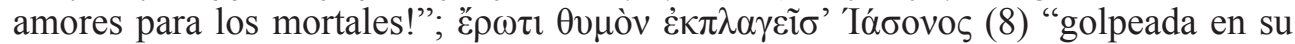

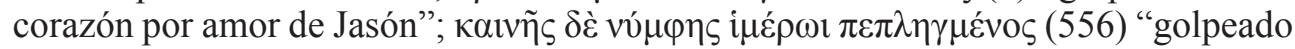

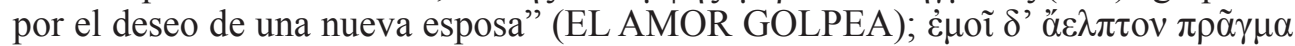

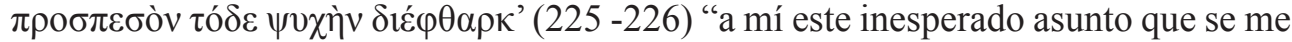

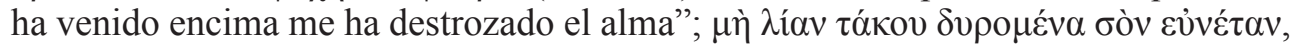
(159) "no te consumas demasiado llorando por tu compañero de cama" (EL AMOR NO CORRESPONDIDO DESTRUYE O CONSUME) y, acudiendo de nuevo al

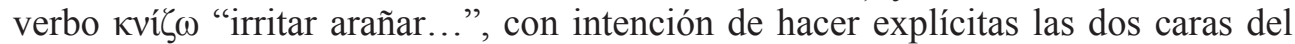

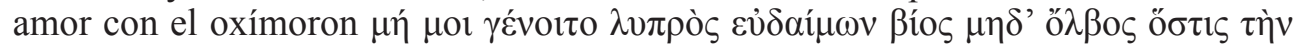

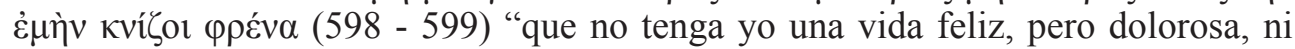
una felicidad que atormente mis sentidos": LA FELICIDAD (QUE PRODUCE EL AMOR) ESCUECE / IRRITA LOS SENTIDOS.

También son bien conocidas desde la literatura arcaica algunas metáforas que apa-

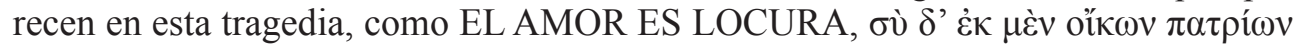

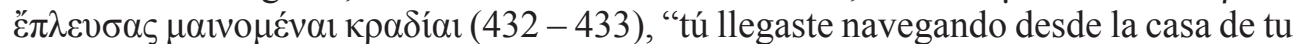
padre, con el corazón enloquecido"; EL DESEO ES UN FLUIDO, que, en este caso, a diferencia de lo que sucedía en Hipólito, se delimita en la expresión metafórica que lo materializa como un veneno impregnado en la punta de una flecha $\mu \eta^{\prime} \pi$ o $\tau$, $\tilde{\omega}$

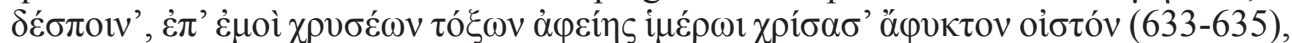
"jamás lances, señora, sobre mí, ungido de deseo, el dardo inevitable de tu dorado

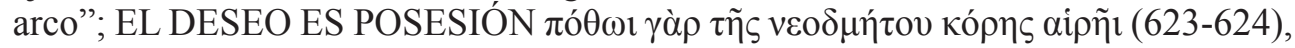
"pues estás apresado por el deseo de tu joven esposa recién casada", cercana a la idea

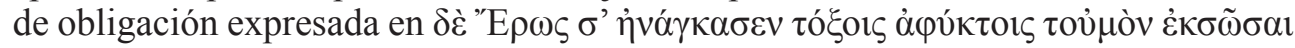
$\delta \varepsilon ́ \mu \alpha \varsigma$ (530-531) "el Amor te obligó con sus inevitables dardos a salvar mi vida...", donde, de nuevo, encontramos una personificación de Eros.

La metáfora EL HOMBRE ES UN CAMPO DONDE SE SIEMBRA EL AMOR, asentada desde la lírica arcaica, vuelve a aparecer con el mismo lexema con que lo

67 Sin embargo, haciendo un juego de palabras bien conocido, el término para designar la cama puede referirse

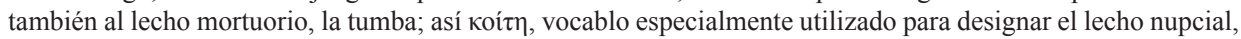

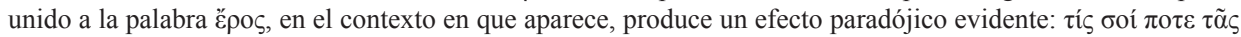

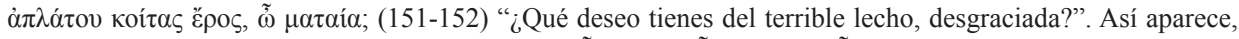

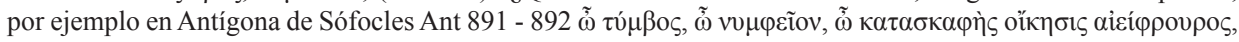
Sófocles, Antígona, así como en diversos epigramas sepulcrales de la Antología Palatina, que hacen referencia al tema de la mors inmatura, $c f$. Hualde (1995: 73-84). 
hacía en Hipólito, vi $\varepsilon \varepsilon \gamma \gamma \alpha ́ \zeta o \mu \alpha$. Así, en un intento de convencer Jasón a Medea de

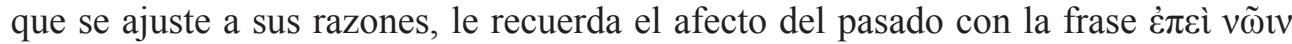

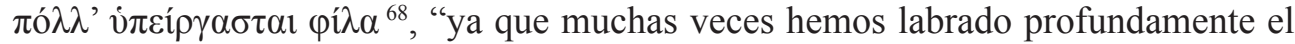
afecto", es decir, "Ya que muchas veces nos hemos tratado con cariño".

Nos queda por reseñar que en Medea, como ya sucedía desde Homero, el amor se concibe como algo externo que sobreviene o llega hasta el hombre, como se deja ver

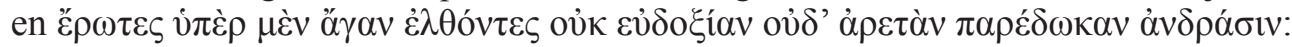
(627 -628), "Cuando los amores llegan en demasía no proporcionan a los hombres

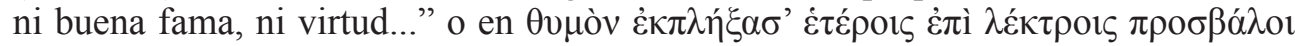

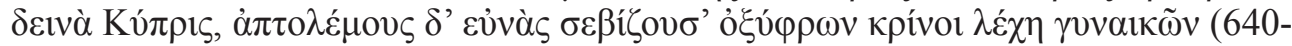
644), "Que Cipris no me sobrevenga terrible, habiéndome golpeado el ánimo con el deseo de lecho ajeno, y que, respetando la cama matrimonial libre de discordia, ella adjudique con agudo juicio los lechos nupciales a las mujeres". Esta sobrevenida del amor, en los términos utópicos propuestos por Eurípides, debería ser moderada,

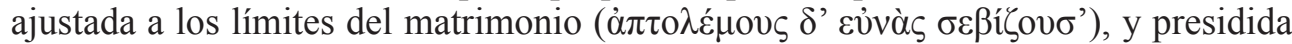
por la sensatez (ózú $\varphi \rho \omega v \kappa \rho i ́ v o r)$. Sin embargo, el propio autor es consciente de que Eros se define, por el contrario, por la falta de mesura y su incapacidad de control en la larga tradición literaria que precede al poeta. La situación deriva en aporía, dando así lugar a la tragedia.

\section{Poesía helenística}

\subsection{Apolonio Rodio. Libro III de las Argonáuticas: El amor que abrasa a fuego lento. La barroquización de la expresión metafórica del amor}

Ya en época alejandrina encontramos una fértil cantera de metáforas amorosas en el canto III de las Argonáuticas de Apolonio Rodio. Este autor dedica todo el libro, que se abre con la invocación a la Musa del amor, a la descripción del enamoramiento de Medea y su consiguiente ayuda al Esónida para conseguir el vellocino antes de huir juntos. Es un texto que presenta una fina caracterización psicológica de los personajes de Medea y de Jasón y que describe en términos dramáticos la pasión amorosa de la joven princesa de la Cólquide. Ello propicia que Apolonio, haciendo gala de su condición de poeta doctus, retuerza alambicadamente metáforas amorosas bien establecidas desde los líricos arcaicos. Destacan, de entre todas, las metáforas en las que se quiere expresar el sufrimiento que produce el amor en la joven hija de Eetes. Se trata de las imágenes clásicas del calor, fuego, dolor y sus consecuencias a las que, con frecuencia, Apolonio da un giro innovador en la expresión metafórica, al elegir lexemas nuevos para la enunciación de viejos esquemas conceptuales e, incluso, nuevas imágenes iconográficas, como la ya esbozada por Eurípides de "las flechas del amor".

Así, la bien conocida metáfora de EL AMOR ES CALOR/ FUEGO se materializa, en primer lugar, como el dardo ardiente con el que el juguetón Eros, aquí ya desarrollado como un personaje más de la obra ${ }^{69}$, desencadena el enamoramiento

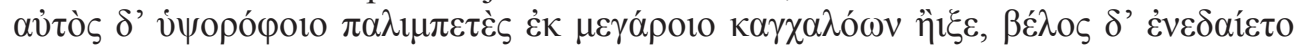

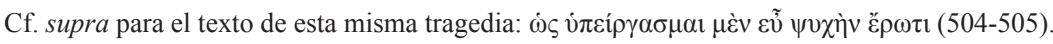

Para la función de Eros como personaje, cf. Pendergraft (1991: 95-102). 


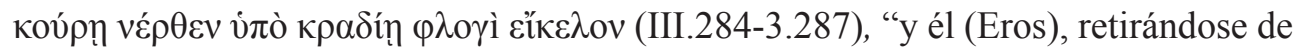
la sala de alto techo, echó a volar riendo a carcajadas; pero la flecha ardía dentro del corazón de la muchacha, semejante a una llama".

Pero el valor metáforico sigue haciédose presente en expresiones no sólo con

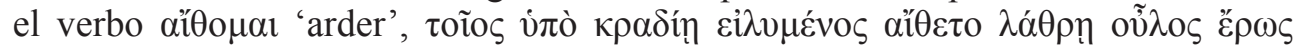
(III.296), "de tal manera el funesto amor encubierto, ocultamente ardía en su corazón", sino con el verbo $\sigma \mu v ́ \chi \omega^{70}$ 'arder a fuego lento, consumirse lentamente en el fuego', que reúne las dos metáforas EL AMOR ES FUEGO /EL AMOR CONSU-

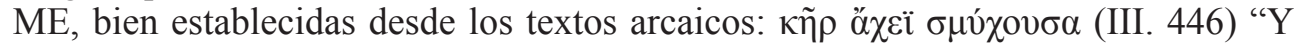
su corazón se consumía a fuego lento por el dolor", y, en amalgama con la metá-

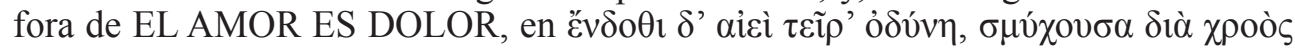
(III.762), "un dolor continuamente la atormentaba, quemándola a fuego lento por toda su carne". Asimismo, la idea de calor subyace en la metáfora EL AMOR HACE DERRETIR AL ENAMORADO que complementa con una poética comparación

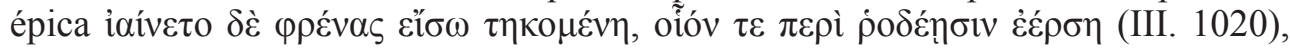
"sentía un calor dentro de sus entrañas que la derretía, como el rocío sobre las rosas".

También Apolonio intensifica la metáfora EL AMOR ES DOLOR haciendo que

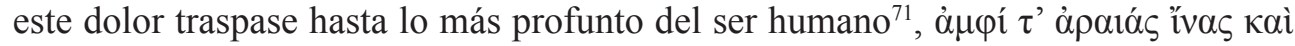

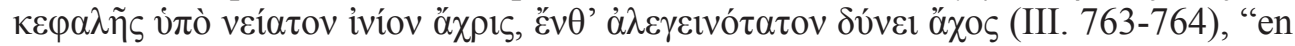
torno a sus delicados nervios y traspasando bajo lo más interno de la nuca, allí donde el sufrimiento penetra de forma más dolorosa", y desarrolla simultáneamente la metáfora EL AMOR ES PROFUNDIDAD, utilizando de forma novedosa el ver-

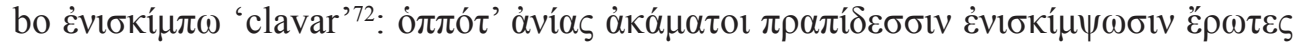
(III.765), "cuando los amores incansables clavan su tormento en las entrañas". Dicho dolor intenso aparece asimismo en amalgama con la idea EL AMOR ES POSE-

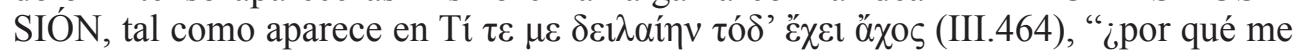
posee este sufrimiento, desgraciada de mí?".

Este tormento amoroso, siguiendo esquemas ya vistos en la lírica y la tragedia, se concibe mediante la metáfora de motivación sinestésica EL AMOR ES SABOREABLE, combinado en amalgama conceptual con la empleada para hablar del amor desde los primeros testimonios literarios EL AMOR ES UN FLUIDO $\gamma \lambda \nu \kappa \varepsilon \rho \eta \tilde{~} \delta \dot{\varepsilon}$

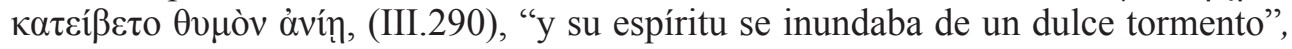
aplicando, en este caso, un oxímoron ya clásico. Esta misma imagen se repite en el

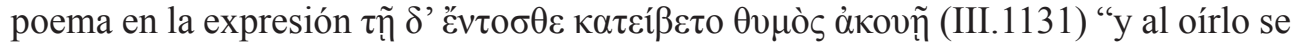
le inundaba el ánimo en su interior". Ello se combina con la metáfora más general

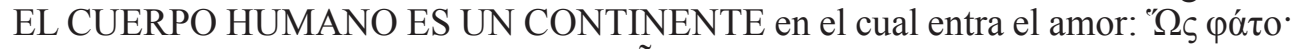

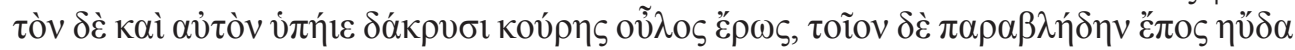
(III.1077-1078), “Así dijo. Y a él también el funesto amor le sobrevenía con las lágrimas de la doncella, y tal discurso pronunció como respuesta". De este continente

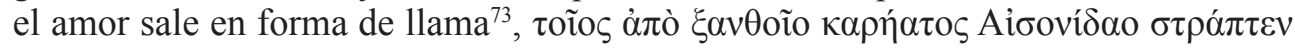

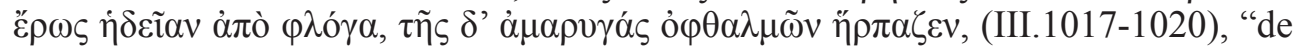
tal manera el amor despedía una dulce llama de la cabeza del rubio Esónida y arre-

También con este significado en Mosch. Fr. 2.4.

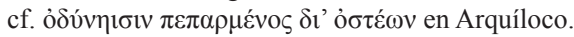

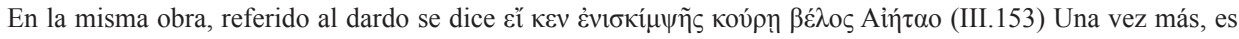
sutil la división entre metáfora conceptual e imagen mítica.

73 Puede remontar a la idea platónica (Fedro 251b) de que el deseo es infundido en el alma del enamorado por la emanación de la belleza que procede del ser querido. 
bataba la claridad de los ojos de ella", pasaje en el que se desarrollan, asimismo combinadas, EL AMOR ES FALTA DE SENTIDOS (CEGUERA) y EL AMOR ES UN LADRÓN ${ }^{74}$. Además, en un claro procedimiento de corporeización, bajo el cora-

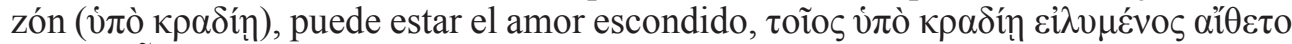

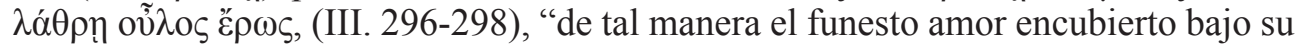
corazón, ocultamente ardía".

Otra metáfora empleada por el épico de Rodas hace referencia al movimiento. La idea, documentada desde la obra de los líricos, es que EL AMOR MUEVE / AGITA AL ENAMORADO. En este caso Apolonio utiliza el verbo ơ $\mu$ í 'soplar/ pas. ser azo-

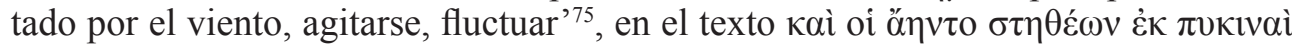

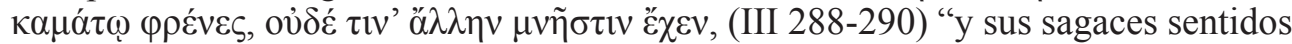
se le volaban del pecho por la zozobra, no tenía memoria para nada más..."76. Relacionada asimismo con la metáfora anterior está la expresión metafórica que concreta que es la mente o el alma la que se arrastra o vuela en pos del ser amado, según el es-

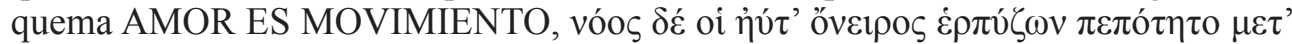

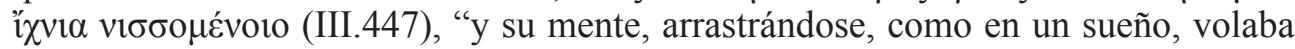

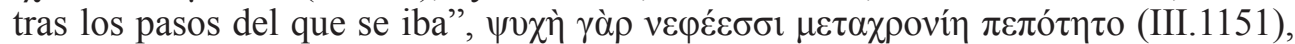
"pues su espíritu volaba más allá de las nubes".

En el mismo sentido cabe interpretar las metáforas opuestas AMOR ES MOVIMIENTO, en las expresión metafórica formulada mediante el verbo ỏ $\tau \rho v ́ v \omega$, y

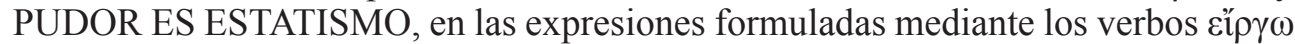

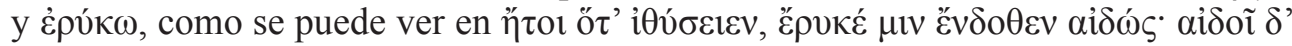

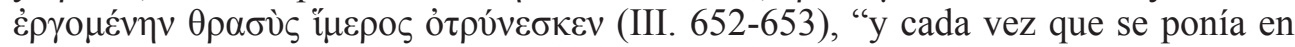
marcha, el pudor la retenía dentro de ella; pero el audaz deseo la empujaba cuando era contenida por el pudor".

En cuanto a los consabidos síntomas del amor, descritos en detalle por vez primera en la literatura griega en el famoso fragmento $31 \mathrm{de} \mathrm{Safo}^{77}$, recordemos una vez más que LOS SÍNTOMAS DEL AMOR SON EL AMOR en forma de metonimia ${ }^{78}$. Así tenemos INCREMENTO DEL RITMO CARDIACO en la expresión metoní-

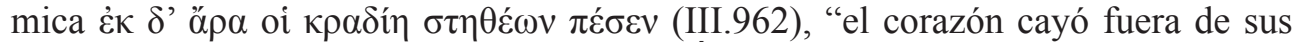

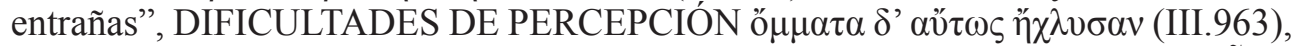

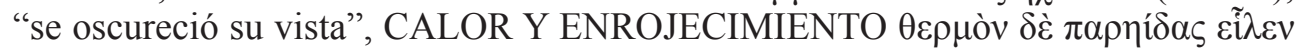

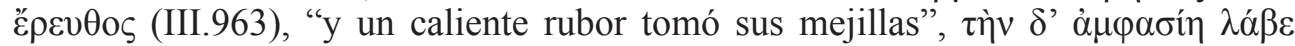
$\theta$ voóv, (III.284), "la imposibilidad de hablar se apoderó de ella".

Finalmente, y dentro de un contexto mitológico, debemos señalar una vez más la metáfora, atestiguada desde Homero, EL AMOR ES MAGIA, por la cual el verbo $\theta \varepsilon \dot{\lambda} \gamma \omega$ 'encantar mediante hechizo' es sinónimo de 'enamorar'. $\Delta \varepsilon \tilde{\rho} \rho$ ' 'io $\mu \varepsilon v \mu \varepsilon \tau \grave{\alpha}$

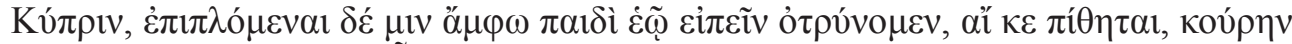

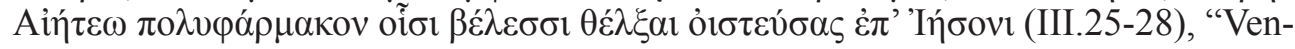

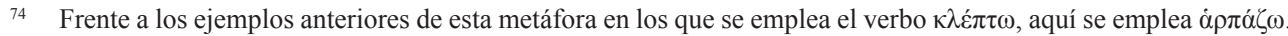

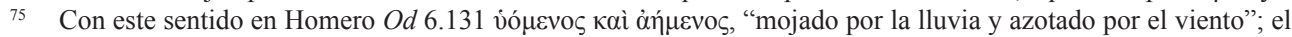

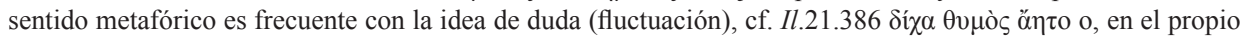

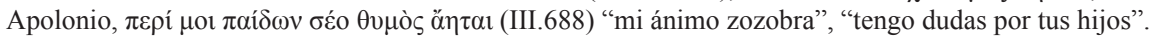

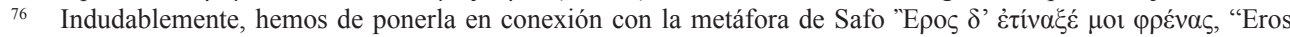

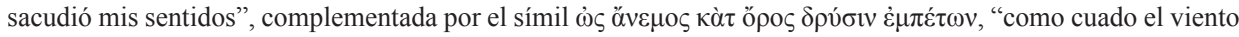
en el monte se abate sobre las encinas".

77 Sobre el modelo sáfico de este pasaje cf. Mignogna (1992: 35-15); Bettenworth 2003 (101-113).

78 Kövecses, (1990: 52); (1986: 101); Santos Domínguez-Espinosa Elorza, (1996: 102). 
ga, vayamos tras Cipris, y cuando estemos junto a ella incitémosla ambas a que hable con su hijo, por si le convence de que con sus flechas encante por Jasón a la hija de Eetes, la de muchos brebajes"; "H

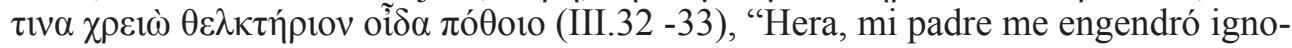
rante de sus flechas, y no conozco ningún otro hechizo provocador del deseo...". Al margen del carácter bien asentado de la metáfora estructural, no parece inmotivada su elección dada la condición de maga y encantadora de Medea, que, sin embargo, será sometida al poder omnímodo de los hechizos de Eros.

\subsection{Teócrito y el Fragmentum Grenfellianum: Fuego, atadura y enfermedad}

Asimismo, la literatura de época helenística es una buena cantera de metáforas sobre el amor, de las que destacamos las que aparecen en boca de dos personajes literarios femeninos: la Simeta del Idilio II de Teócrito y la anónima enamorada del papiro de Grenfell, quienes presentan la novedad de desempeñar un papel activo como desencadenante de la relación sexual ${ }^{79}$.

El siracusano Teócrito, creador de un nuevo género, el idilio, la figurilla helenística que nos hace llegar a pinceladas, bien una idealizada escena campestre, bien un pequeño episodio realista urbano, retoma el asunto de la amante abandonada en el Idilio II, Las hechiceras. Esta escenita urbana del alejandrino tiene, como es sabido, una estructura bipartita y nos muestra, en la primera parte, a la joven Simeta, que, tras haber sido abandonada por su amante, ayudada por su esclava Téstilis, Delfis, está realizando un sortilegio, con el que se pretende el regreso del traidor. En la segunda parte de la obra sabemos, por boca de la joven, cómo sucedió su primer encuentro con el apuesto Delfis en el transcurso de una procesión religiosa, su posterior encuentro sexual y, finalmente, el abandono.

Un caso paralelo presenta el texto del llamado Papiro de Grenfell, por el nombre del primer editor de la obra en $1897^{80}$. Aunque menos detallado por haberse conservado sólo de forma fragmentaria, plantea asimismo el tema de la amante abandonada que habla en primera persona y presenta grandes concomitancias con el Idilio II de Teócrito, como obras pertenecientes a una misma cronología (III-II a.C.) y a un mismo marco geográfico.

Al ser el texto, amén de fragmentario, bastante más corto que el del siracusano, así como por centrarse en el lamento femenino tras el abandono más que en la narración de los hechos previos, tenemos mucha menos información sobre la historia de la relación de esta abandonada anónima, aunque una de las claras coincidencias entre ambas mujeres literarias, es en las referencias al amor como FUEGO, POSESIÓN Y LOCURA O ENFERMEDAD ${ }^{81}$.

Así, en un estrecho paralelismo entre la Simeta de Teócrito y la enamorada del Anónimo, ambas mujeres expresan de forma extraordinariamente próxima la idea de la combustión completa de su ser (según la metáfora EL AMOR ES FUEGO) por

\footnotetext{
79 Sobre el abandono del esquema de la pasividad femenina y sus causas Brioso Sánchez, (2000:153 y 200).

80 Texto encontrado en un papiro de la Tebas alejandrina, escrito en el siglo II a.C y que presenta el lamento de una muchacha abandonada por su amante. El texto, anónimo, recibe el nombre de su primer editor, Grenfell (1896:1-6). Un estudio reciente sobre este texto es el de Esposito (2002:199-214). Valoración general de paralelismos entre el II de Teócrito y el , así como los elementos euripideos en esta obra, en Hunter, (1996:7-10).

81 Para el desmonte de la metáfora en el ritual propiciatorio de Simeta y sus evidentes elementos intertextuales cf. Hualde (2017).
} 


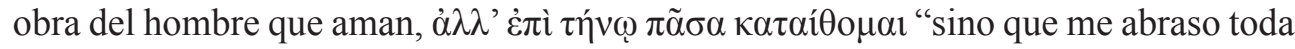

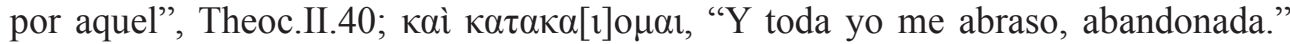
Mim.Fr.Pap.I.24, y presentan, asimismo, la coincidencia de situar este fuego en una

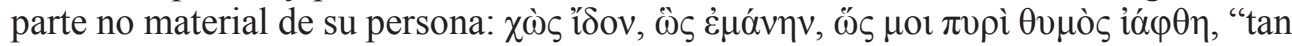

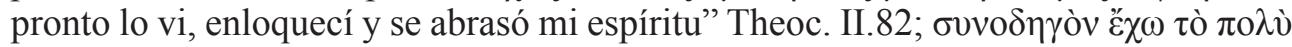

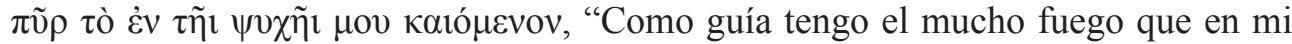
alma arde," Mim.Fr.Pap. I.15-16.

EL AMOR Y LOS CELOS SON POSESIÓN O ATADURA: Tanto la pasión no satisfecha como los celos se conciben como entidades capaces de posesión, lo que hace que los nombres de estos sentimientos puedan ser sujetos de verbos que tienen

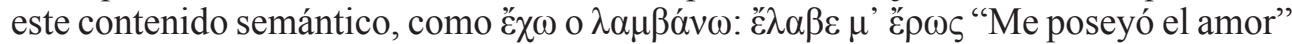

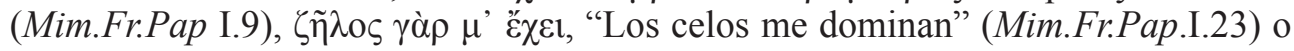

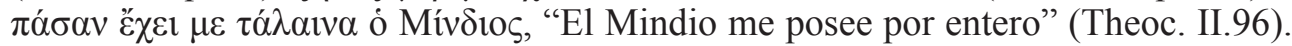
Muy cercana a la idea de posesión o retención aparece la noción, ya tradicional, del amor o del deseo como atadura o como elemento en el que queda aprisionado

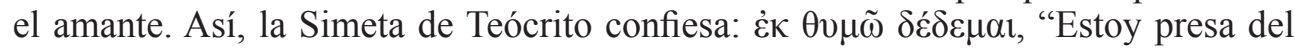
deseo." (Theoc. II.60).

EL AMOR APASIONADO ES LOCURA Y ENFERMEDAD: El inicio de su enamoramiento es definido por Simeta como locura, "tan pronto lo vi, enloquecí y se abrasó mi espíritu" Theoc.II.82, y la locura como resultado del amor es tam-

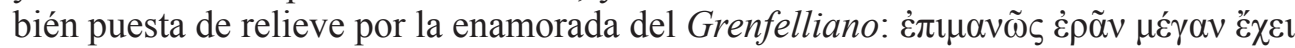

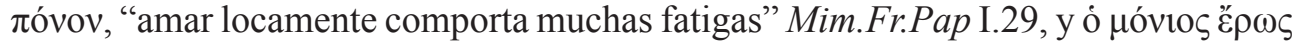

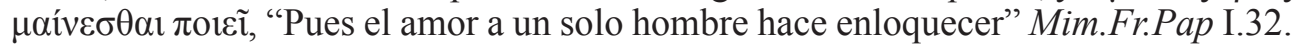

Ambas mujeres mostrarán, en consecuencia, la enfermedad como respuesta a su amor no correspondido: Simeta lo presenta en una larga descripción de la somatiza-

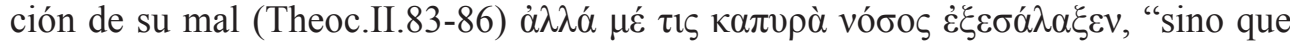
una agostadora enfermedad me consumía", expresión que concreta la metáfora EL AMOR AGOSTA / EL SENTIMIENTO ES UN CAMPO, mientras que la protago-

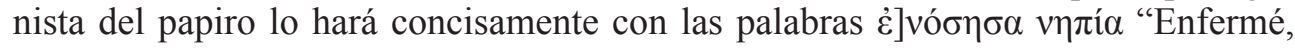
tonta de mí" Mim.Fr.Pap. II.60.

Al margen de los paralelismos entre ambos textos, el del siracusano permite ver más detalladamente esquemas conceptuales sobre el amor. Es el caso de la descripción de los síntomas eróticos -como ya vimos en $\mathrm{Safo}^{82}$ y en Apolonio que conceptualmente, recordemos, se formula como LOS SÍNTOMAS DEL AMOR SON EL AMOR en forma de metonimia ${ }^{83}$. Así podemos mencionar SUDOR FRÍO,

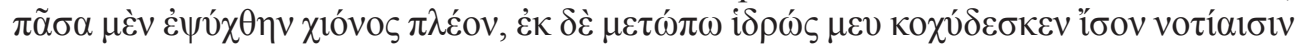
غ̇é $\rho \sigma \alpha ı \zeta$, "Me quedé toda más fría que la nieve, pero del rostro me resbalaba un sudor

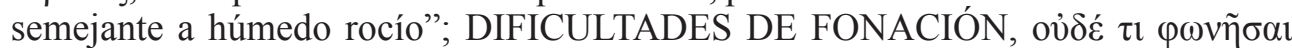

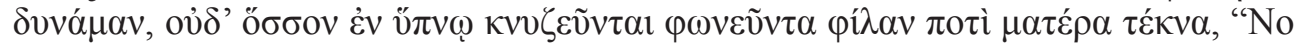
era capaz de decir nada, ni siquiera los vagidos con que en sueños habla el bebé a su

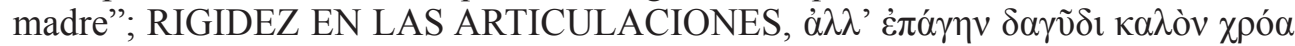
$\pi \alpha ́ v \tau o \theta \varepsilon v$ '̌ $\sigma \alpha$, "sino que mi hermoso cuerpo se quedó todo rígido como el de una muñeca".

Finalmente, para designar la relación sexual, la protagonista se sirve de dos eufemismos metafóricos: en uno de ellos se concibe el amor como una extensión de

\footnotetext{
82 Para el modelo sáfico del pasaje cf. Pretagostini (1977: 107-118).

83 Kövecses (1990: 52); (1986:101); Santos Domínguez- Espinosa Elorza, (1996: 102).
} 


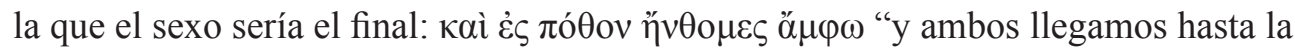
culminación del deseo", y en el otro se refiere a la realización del acto sexual como

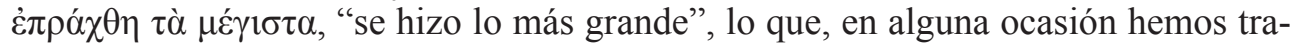
ducido como "pasamos a mayores" $"$.

\section{Conclusiones}

Tras la revisión de un corpus de textos que hemos considerado representativo podemos llegar a las siguientes conclusiones generales:

El hombre griego concibe la pasión amorosa no como algo que se genera en su interior, sino que le sobreviene externamente y se aloja en él. Sobre esa base cognitiva se generan una serie de metáforas ontológicas (AMOR ES UN ARMA ARROJADIZA, UN FLUÍDO, UNA CARGA con el desarrollo literario de la metáfora que supone que el AMOR ES UNA SEMILLA y la metáfora estructural AMOR ES PROFUNDIDAD EN EL INTERIOR HUMANO.

Consecuentemente se concibe que EL HOMBRE ES UN RECIPIENTE en el que se introduce el amor, y tenemos muy escasos datos de la metáfora contraria en la que es EL AMOR ES UN RECIPIENTE EN EL QUE SE SUMERGE EL SER HUMANO.

El hombre griego se siente impotente ante el carácter irracional e incontrolable del amor y de ahí provienen las metáforas estructurales que interpretan que EL AMOR ES MAGIA, LOCURA, BORRACHERA, JUEGO (DE AZAR O DE NINOS) O FALTA DE SENTIDOS en general.

El hombre griego siente, pues, el amor como una agresión que lo domina, lo que puede justificar la presencia de las metáforas estructurales AMOR ES DOMINACIÓN O SOMETIMIENTO, GUERRA, CAZA O PERSECUCIÓN así como ATADURA, POSESIÓN U OBLIGACIÓN. Sobre la metáfora conceptual que identifica amor con lucha se desarrolla la metáfora o imagen literaria del BOXEO CON EROS.

El amor, por tanto, se presenta en la poesía como algo mayoritariamente negativo para el hombre, como causa de sufrimiento, lo que permite justificar las metáforas AMOR ES DOLOR, GOLPE, HERIDA, MORDEDURA, ROTURA ESCOCEDURA, DESGASTE, o, sencillamente, MUERTE.

La violencia de que se dota conceptualmente al amor permite que éste se asocie con movimiento brusco sobre el ser humano, mediante las metáforas AMOR ES MOVIMIENTO O AGITACIÓN DEL ESPÍRITU.

Merece la pena destacar por su productividad algunas metáforas que presentan evidente motivación sinestésica, como es AMOR ES DULCE, AMARGO O DULCEAMARGO.

Terminamos con la alusión a las metáforas de motivación metonímica, si suponemos que los efectos del amor son el amor en forma de metonimia. En este caso tenemos las metáforas que suponen que EL AMOR ES CALOR QUE PUEDE HACER DERRETIRSE, ENROJECIMIENTO, SUDORES, TEMBLOR, DIFICULTADES FONATORIAS, VISUALES Y AUDITIVAS, INCREMENTO DEL RITMO

$84 \quad$ Hualde (2011). 
CARDIACO, RIGIDEZ DE EXTREMIDADES O, la compartida por la épica y el Eurípides del Hipólito, DEBILIDAD EN LAS ARTICULACIONES.

Para mayor claridad y como síntesis de los textos analizados, presentamos unos cuadros de resultados en los que se destacan los siguientes campos: La metáfora cognitiva empleada (con indicación sobre si es orientacional, ontológica o estructural); la expresión metafórica concreta; la base conceptual que subyace en dicha metáfora; si existe sobre esa base conceptual una metáfora o imagen literaria, y nuestra traducción del texto. Añadimos información en el caso de que la metáfora conceptualmente tenga una motivación metonímica o una motivación sinestésica, y si se trata de una metáfora con implicaciones valorativas, además de señalar elementos estilísticos en la expresión metafórica, caso de la presencia de oxímoron o paradoja.

\section{Bibliografía}

Adrados, F.R. (1995), Sociedad, amor y poesía en la Grecia antigua, Madrid, Alianza.

Alamillo, A. (1981), Sófocles, Tragedias, Colección Biblioteca. Clásica Gredos, Vol. 40.

Barcelona Sánchez, A. (1992), "El lenguaje del amor romántico en inglés y en español”, en Atlantis XIV 1-2, Murcia 1992, 5-27.

Beger, A. - Jäkel, O. (2009), "ANGER, LOVE and SADNESS revisited: differences in emotion metaphors between experts and laypersons in the genre psychology guides", en $\mathrm{Me}$ taphorik.de 16/2009, 87-108.

Bettenworth, A. (2003), "Ovid, Apollonius und Sappho: die Liebessymptomatik der Medea in Ov. Met. 7, 74-88", Philologus 147 (1), 101-113.

Brioso Sánchez, M. (2000) “El amor, de la Comedia Nueva a la Novela”, en M. Brioso Sánchez y A. Villarrubia Medina (edd.), Consideraciones en torno al amor en la literatura de la Grecia antigua, Sevilla.

Brown (1987) Sophocles: Antigone, Warminster.

Boys-Stone, G.R. (2003), Metaphor, Allegory, and the Classical Tradition, Oxford, U.P.

Cabello Pino M. (2006), "El tópico de la enfermedad de amor en el Hipólito de Eurípides", en Manual práctico para la innovación docente en la Teoría de la Literatura y la Literatura Comparada, 29-47.

Cabello Pino M. (2012), "El tópico de la enfermedad de amor en la literatura griega de época helenística", Revista Esfera n 3, 38-57.

Cairns, D. (2016) "Mind, Body, and Metaphor in Ancient Greek Concepts of Emotion", L'Atelier du centre de recherche historique 16, 2-18.

Dodds, E. R. (1983), Los griegos y lo irracional, Madrid, Alianza.

Douterelo, E. (1997), "El léxico y el tema del amor en Las Traquinias de Sófocles", Cuadernos de filología clásica. Estudios griegos e indoeuropeos, 7, 195-206.

Esposito, E. (2002), "Il pubblico del mimo popolar e nell'Egitto tolemaico: Dryton e il Grenfellianum”, Eikasmos, 13, 199-214.

Fauconnier G.- Turner M. (2002), The Way We Think: Conceptual Blending and the Mind's Hidden Complexities, New York, Basic Books.

Fauconnier, G. - Turner, M. (1998), "Conceptual Integration Networks", Cognitive Science, 22, 2: 133-187.

Flory, S. (1978), "Medea's right hand. Promises and revenge", Transactions of the American Philological Association; CVIII, 69-74. 
Gentili, B. (1972), “Il « letto insaziato » di Medea e il tema dell'adikia a livello amoroso nei lirici (Saffo, Teognide) e nella Medea di Euripide", Studi classici e orientali, XXI, 60-72.

Gibbs, R. W. (2008), The Cambridge handbook of metaphor and thought, Cambridge University Press.

Gibert, (2000), «Falling in Love with Euripides (Andromeda)», ICS 24/25, 75-91.

Gonzalvez-Garcia, F. (2013), Metaphor and metonymy revisited beyond the contemporary theory of metaphor recent developments and applications, John Benjamins Publishing Company.

Grady, J.E., Oakley, T. \& Coulson, S. (1999), "Blending and Metaphor", in: Gibbs, R. \& Stehen, G. (Eds.), Metaphor in cognitive linguistics. (Selected papers from the Fifth International Cognitive Linguistics Conference), Amsterdam, 101-124.

Grenfell, B.P. (1896), An alexandrian erotic fragment and other greek papyri, Oxford, pp. $1-6$.

Handl, S. - Schmid, H.J. (eds.) (2011), Windows to the Mind: Metaphor, Metonymy and Conceptual Blending, Berlin/New York: de Gruyter.

Hualde, P. (2011), "Las otras Ariadnas: mujeres abandonadas en la literatura clásica", en Ideas de mujer: facetas de lo femenino en la Antigüedad / coord. por Rosario López Gregoris, Luis Unceta Gómez, 2011, 131-158.

Hualde, P. (2016), "Metáforas del amor en la poesía de la Grecia antigua (I): La épica y la lírica arcaica", $C F C$ (g): Estudios griegos e indoeuropeos 26, 17-47.

Hualde (2017), "Metáfora y magia en La Hechicera de Teócrito", Ágora : estudos clássicos em debate, 18, 51-79 (en prensa)

Hunter, R. (1996), Theocritus and the Archaeology of Greek Poetry, Cambridge.

Kamerbeek, J. C. (1959) (J. C.), The plays of Sophocles (Commentaries) II: The Trachiniae. Leiden, E. J. Brill.

Kövecses, Z. (1988), The Language of Love. The Semantics of Passion in Conversational English. Lewisburg, PA, Bucknell University Press.

Kövecses, Z. (1986), Metaphors of anger, pride and love, Amsterdam / Philadelpha, John Benjamins.

Kövecses, Z. (1989), The language of Love, London and Toronto, Associated University Press.

Kövecses, Z. (1990), Emotion concepts, Nueva York, Springer Verlag.

Kövecses, Z. (2005), Metaphor in Culture: Universality and Variation, Cambridge University Press.

Lakoff, G. - Johnson, M. (1986), Metáforas de la Vida Cotidiana, Madrid, Cátedra.

Lakoff, G. - Turner, M. (1989), More than Cool Reason. A Field Guide to Poetic Language, London, The University of Chicago Press.

Lasso de la Vega, J. (1990), "El Himno al Amor de Sófocles (Antígona 781-800)", en De la Grecia Arcaica a la Roma Imperial (Cursos de verano de El Escorial, 1989) Editorial Complutense, 55-79.

Lévy, E. (1985), “Inceste, mariage, sexualité dans les Suppliantes d'Eschyle”, en La femme dans le monde méditerranéen, Lyon, pp. 29-45.

Lisarrague, F. (1995), "Women, Boxes, Containers: Some Signs and Metaphors", en Reeder, E.D. (ed.), Pandora. Women in Classical Greece, Princeton, 91-101.

Macartur, F. (2012), Metaphor in use context, culture, and communication, Amsterdam, John Benjamins.

MacCormac (1985: 53-78), A cognitive theory of metaphor, Cambridge, The MIT Press. 
Márquez Guerrero, M. A. (2004), “La metáfora 'el amor es una enfermedad' en el Hipólito de Eurípides”, en Esteban Torre (coord.), Actas del IV Simposio Interdisciplinar de Medicina y Literatura, Sevilla: 43-63.

Mignogna, E. (1992), “Apollonio Rodio davanti a Saffo (Fr. 31 Voigt)”, RCCM 34, 5-15.

Morenilla, C. (2013), “A la búsqueda de la armonía cívica perdida: Eros, Afrodita y la reformulación dramática en las tragedias tardías de Sófocles", Exemplaria Classica. Journal of Classical Philology 17, 2013, pp. 5-26.

Pagán Cánovas, C. (2009), La emisión erótica en la poesía griega: una familia de redes de integración conceptual desde la Antigüedad hasta el siglo xx. Tesis doctoral, Universidad de Murcia.

Pagán Cánovas, C. (2010), "Erotic Emissions in Greek Poetry: A Generic Integration Network”, Cognitive Semiotics 6. 7-32.

Pagán Cánovas, C. (2011). "The Genesis of the Arrows of Love: Diachronic Conceptual Integration in Greek Mythology”, American Journal of Philology 132:4. 553-579.

Pendergraft, M. L. B. (1991), "Eros Ludens: Apollonius’ Argonautica 3, 132-41”, Materiali e discussioni per l'analisi dei testi classici 26, 95-102.

Pralon, D. (1993), "L'éloge d'Aphrodite (Sophocle, 941 Radt)", Sophocle: le texte, les personnages, Provence, 125-131.

Pralon, D. (1993), “L'éloge d'Aphrodite (Sophocle, 941 Radt)”, Sophocle: le texte, les personnages, Provence, 1993, 125-131.

Pretagostini R. (1977), “Teocrito e Saffo. Forme allusive e contenuti nuovi (Theocr. 2,82 sgg., 106 sgg. e Sapph. 31,7 sgg. L.-P.)”, QUCC 24, 107-118.

Pretagostini, R. (1990), "Le metafore di Eros che gioca: da Anacreonte ad Apolonio Rodio e ai poeti dell'Antologia Palatina", AOIN (filol) 12: 225-238.

Ruiz de Mendoza, F. J. (1998), «On the nature of blending as a cognitive phenomenon», Journal of Pragmatics 30/3: 259-274.

Sanders, E. (2013), "Sexual jealousy and erôs in Euripides' Medea", Erôs in ancient Greece, $41-58$

Santos Domínguez, L.A. - Espinosa Elorza, R. M., Manual de Semántica Histórica, Madrid, Síntesis, 1996, 102.

Saravia de Grossi, M.I., (2007), "La presencia de Eros en la poesía dramática de Sófocles", Classica (Brasil) 20.2, 167-181

Schmid, H.J. - Handl, S. (2011), Windows to the Mind. Metaphor, Metonymy and Conceptual Blending, De Gruyter, Mouton.

Shore, B. (1996), Culture in Mind: Cognition, Culture, and the Problem of Meaning, Oxford University Press.

Spatafora, G. (2003), “«La tempesta del mio cor»: storia di una metafora della poesia arcaica al romanzo bizantino", Aevum(ant), 3 (2003) 567-591.

Steen, G. - Gibbs, R. (1999), Metaphor in cognitive linguistics, Philadelphia. O Grady, Oakley, \& Coulson (1999)

Zeitlin, F.I. (1996), "The Politics of Eros in the Danaid Trilogy of Aeschylus”, en Playing the Other. Gender and Society in Classical Greek Literature, Chicago, pp. 123-171. 


\section{Apéndice: Cuadros de metáforas del amor en la poesía griega antigu}

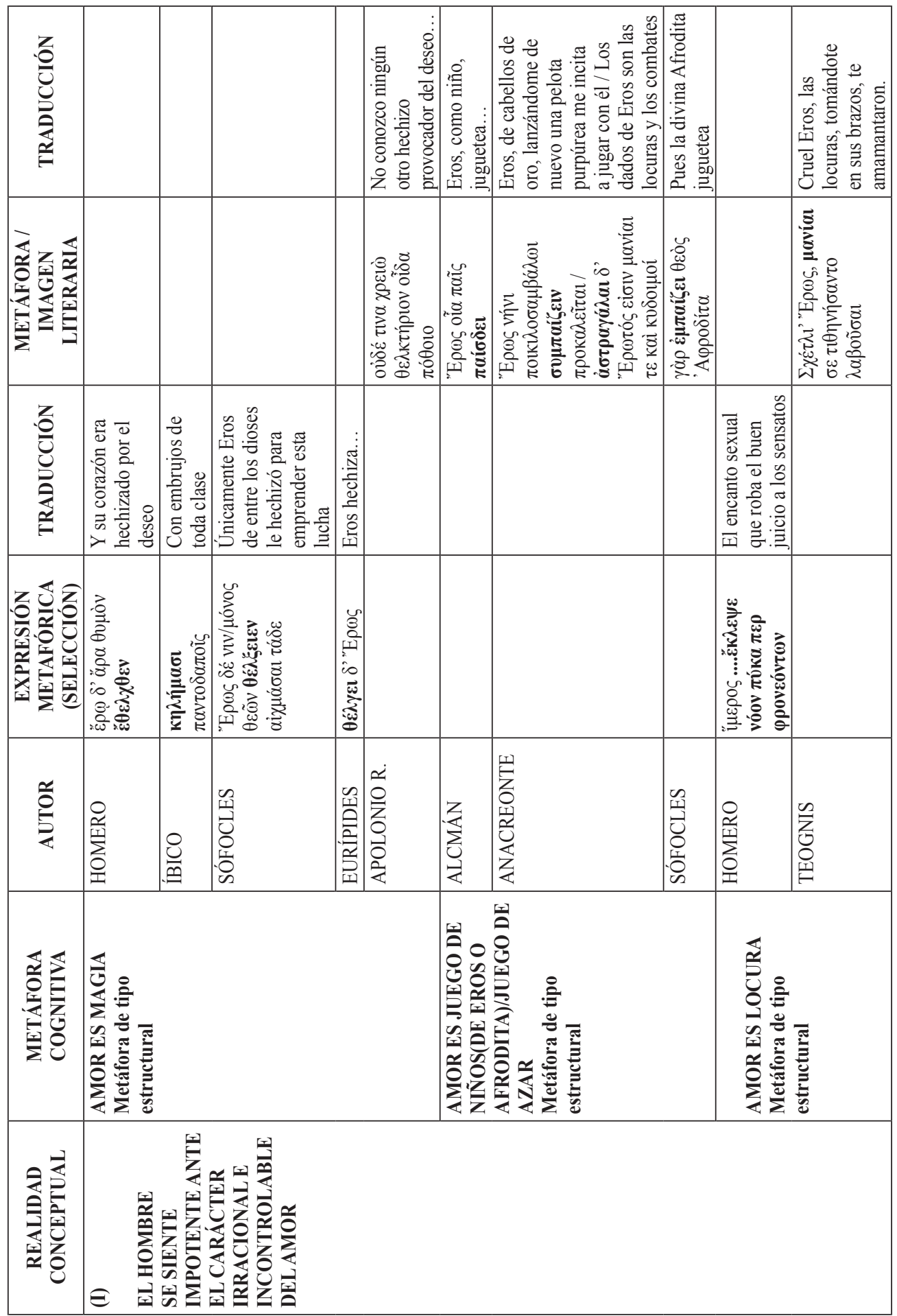




\begin{tabular}{|c|c|c|c|c|c|c|c|c|c|c|c|c|c|}
\hline 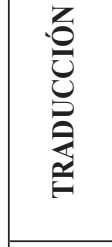 & 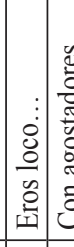 & 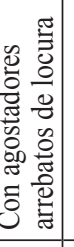 & & & & & & & & & & & \\
\hline 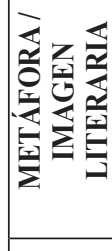 & 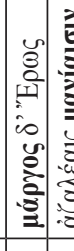 & 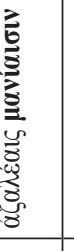 & & & & & & & & & & & \\
\hline 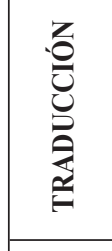 & & & 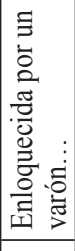 & 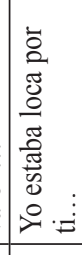 & 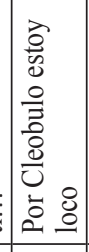 & 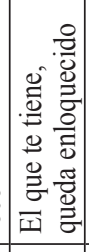 & 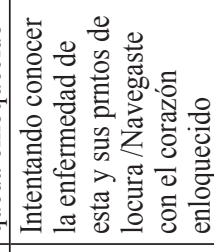 & 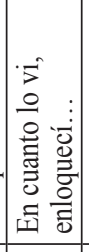 & 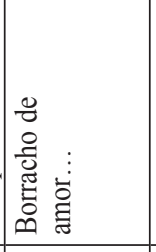 & 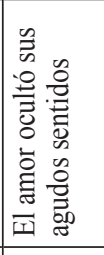 & 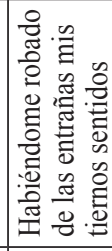 & 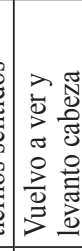 & 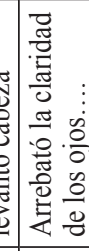 \\
\hline 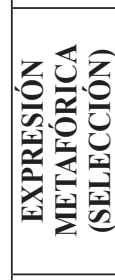 & & & 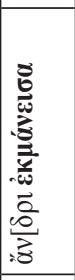 & 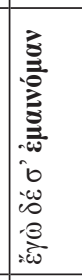 & 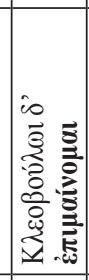 & 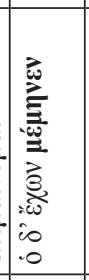 & 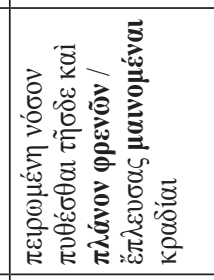 & 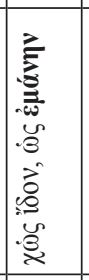 & 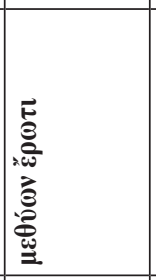 & 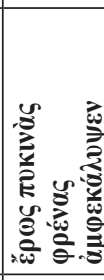 & 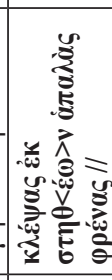 & 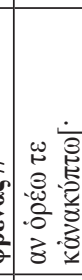 & 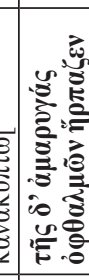 \\
\hline 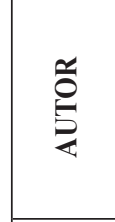 & 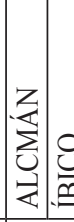 & & 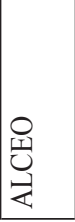 & $\begin{array}{l}0 \\
\text { 足 } \\
\text { 出 } \\
\end{array}$ & 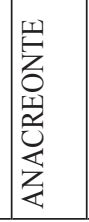 & 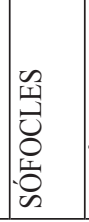 & 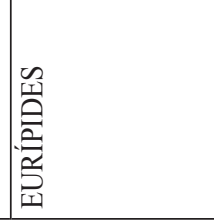 & 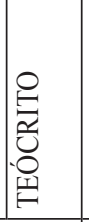 & 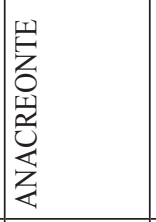 & 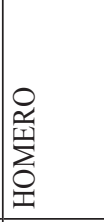 & 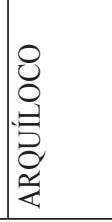 & 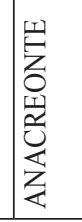 & 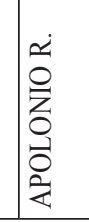 \\
\hline 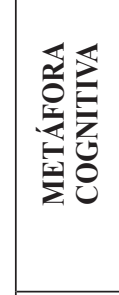 & \multicolumn{8}{|c|}{ 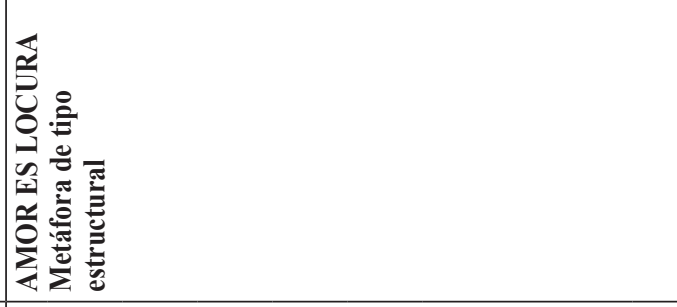 } & \multicolumn{4}{|c|}{ 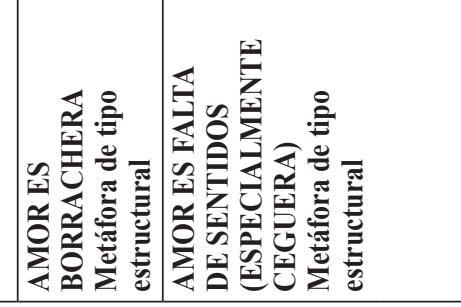 } & \\
\hline 这 & 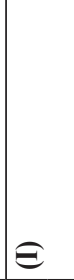 & 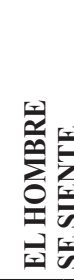 & s. & 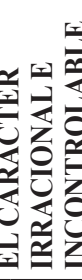 & & & & & & & & & \\
\hline
\end{tabular}




\begin{tabular}{|c|c|c|c|c|c|c|c|c|c|c|c|}
\hline 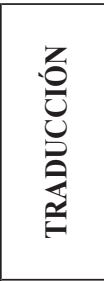 & & & & 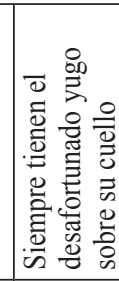 & & & 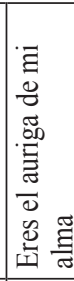 & \multicolumn{2}{|c|}{ 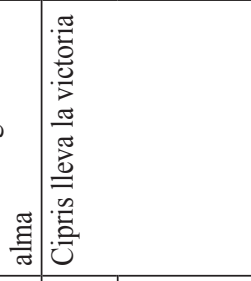 } & 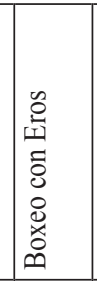 & 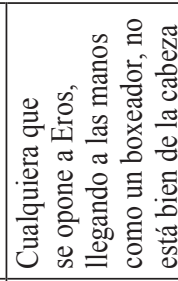 \\
\hline 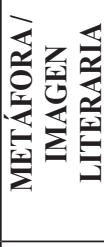 & & & & 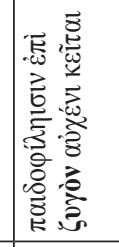 & & & 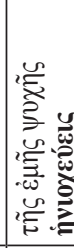 & 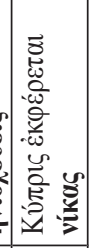 & & 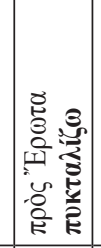 & 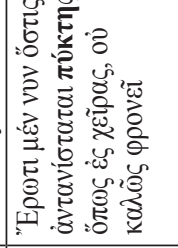 \\
\hline 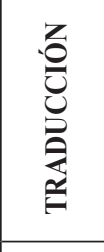 & 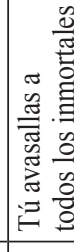 & 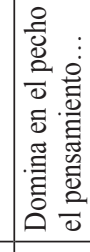 & 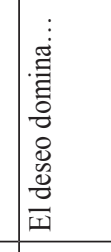 & 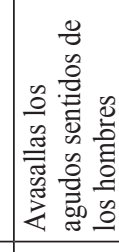 & 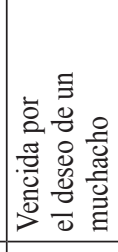 & 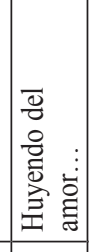 & & & 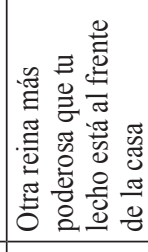 & & \\
\hline 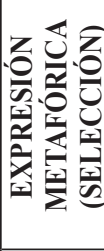 & 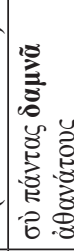 & 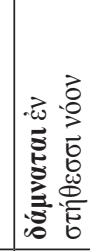 & 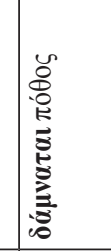 & 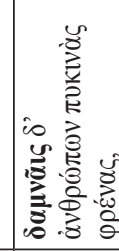 & 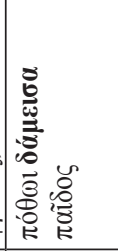 & 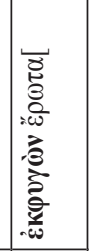 & & & 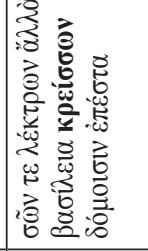 & & \\
\hline 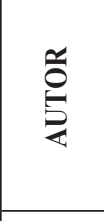 & 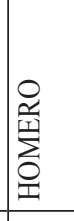 & 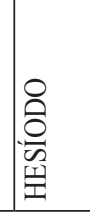 & 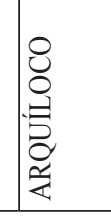 & 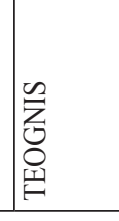 & 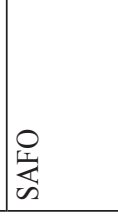 & $\begin{array}{l}0 \\
\text { 足 } \\
\text { 艺 } \\
\end{array}$ & 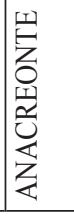 & 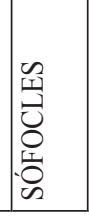 & 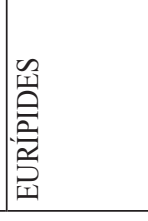 & 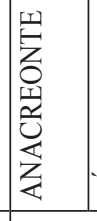 & 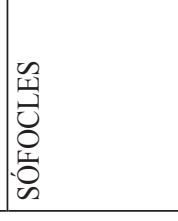 \\
\hline 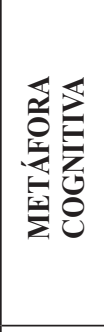 & 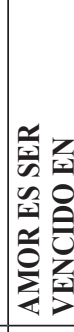 & 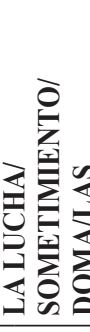 & 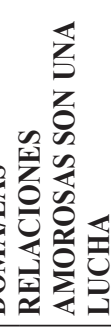 & 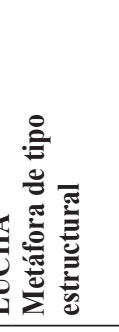 & & & & & & 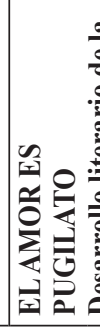 & 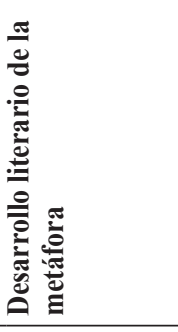 \\
\hline 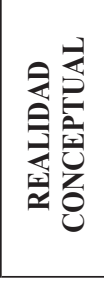 & 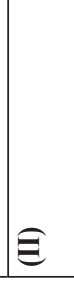 & 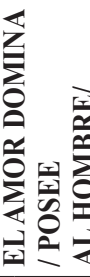 & 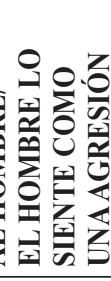 & & & & & & & & \\
\hline
\end{tabular}




\begin{tabular}{|c|c|c|c|c|c|c|c|c|c|}
\hline 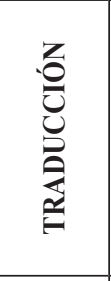 & & & & & 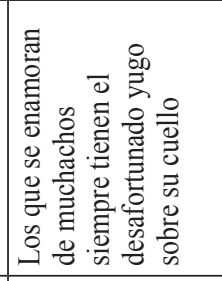 & 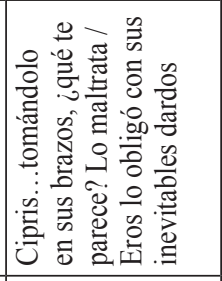 & & & \\
\hline 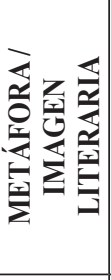 & & & & & 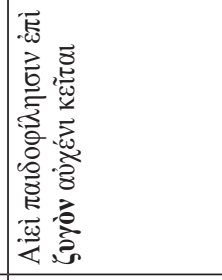 & 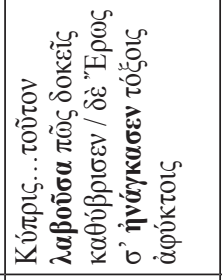 & & & \\
\hline 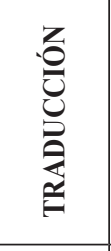 & 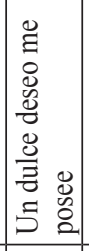 & 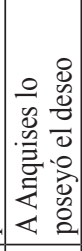 & 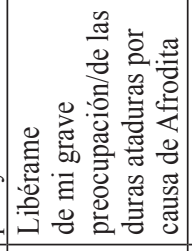 & 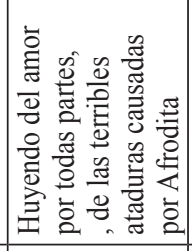 & 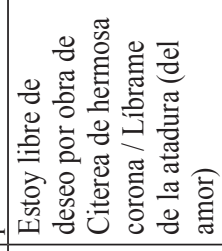 & 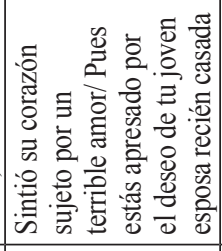 & 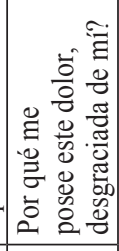 & 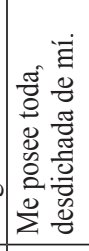 & 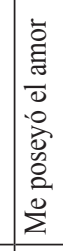 \\
\hline 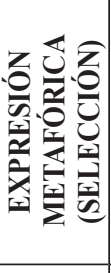 & 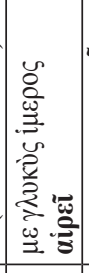 & 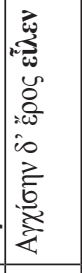 & 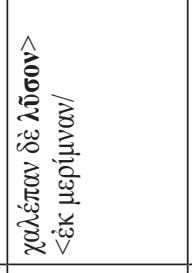 & 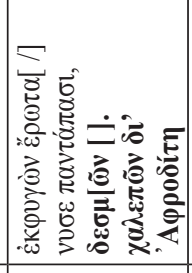 & 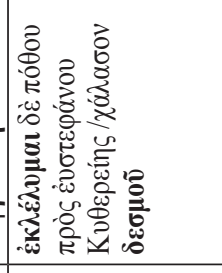 & 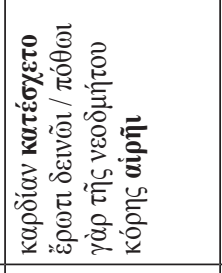 & 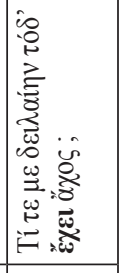 & 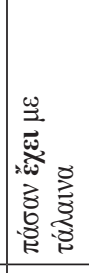 & 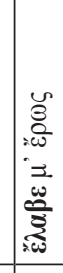 \\
\hline $\begin{array}{l}\text { 号 } \\
\stackrel{3}{4}\end{array}$ & 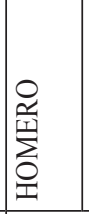 & 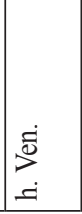 & \begin{tabular}{|l}
0 \\
至 \\
足
\end{tabular} & 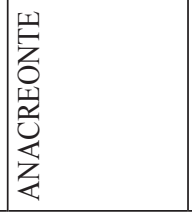 & 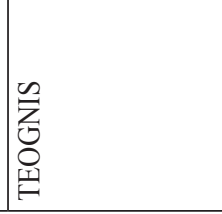 & 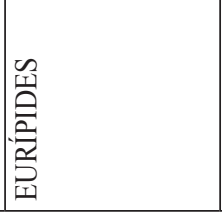 & 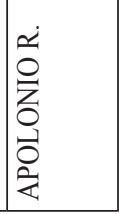 & 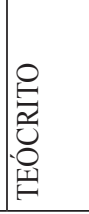 & 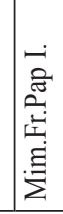 \\
\hline 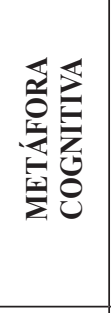 & 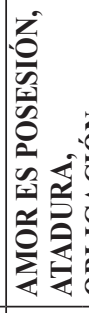 & & & & & & & & \\
\hline 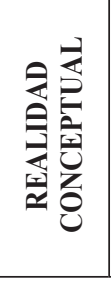 & $\widehat{\Xi}$ & 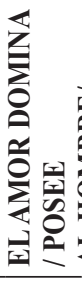 & 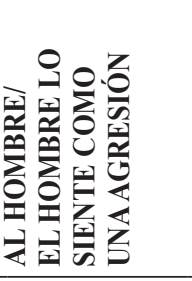 & & & & & & \\
\hline
\end{tabular}




\begin{tabular}{|c|c|c|c|c|c|c|c|c|c|}
\hline 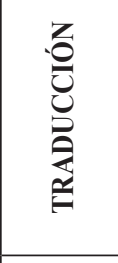 & & & & & 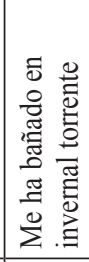 & 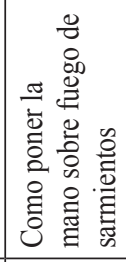 & 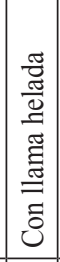 & & \\
\hline 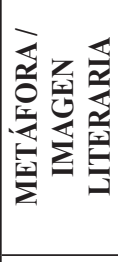 & & & & & 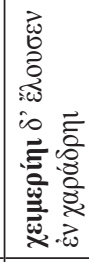 & 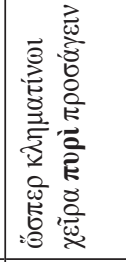 & 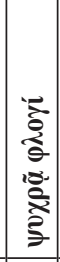 & & \\
\hline 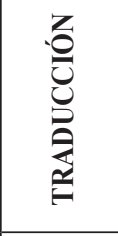 & & 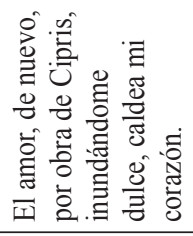 & 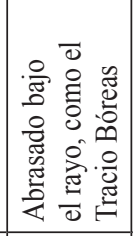 & 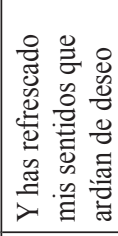 & & 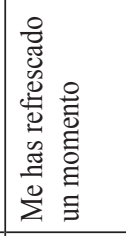 & & 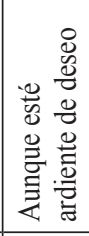 & 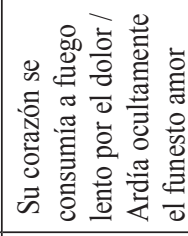 \\
\hline 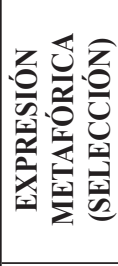 & & 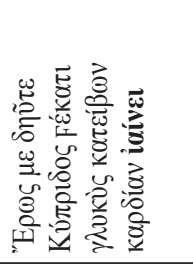 & 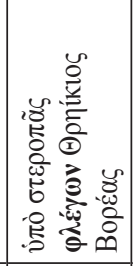 & 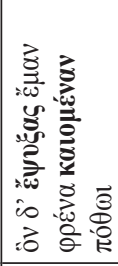 & & 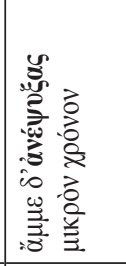 & & 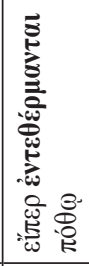 & 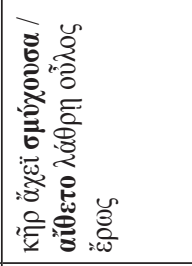 \\
\hline 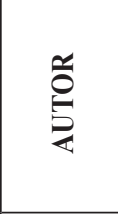 & 留 & 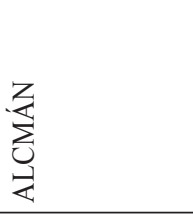 & $\stackrel{\mathscr{\theta}}{\mathscr{\theta}}$ & $\begin{array}{l}0 \\
\text { 至 } \\
\text { 出 }\end{array}$ & 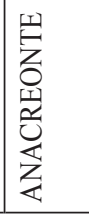 & 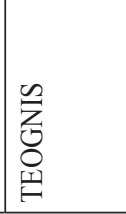 & 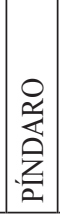 & 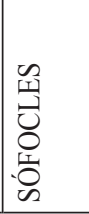 & 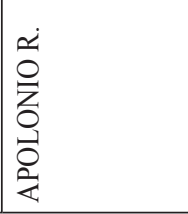 \\
\hline 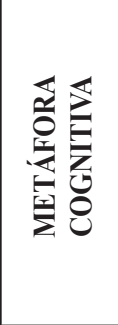 & 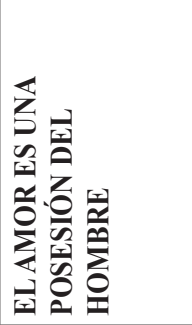 & 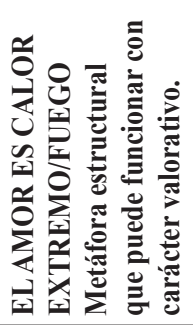 & 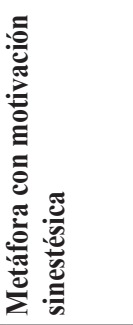 & & & & & & \\
\hline 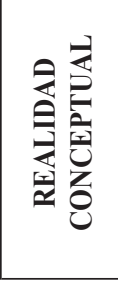 & 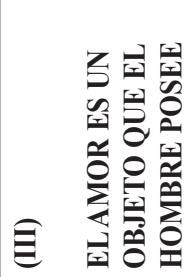 & 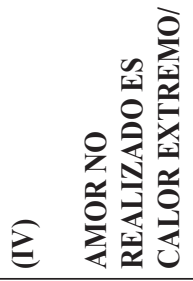 & 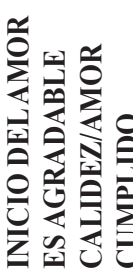 & 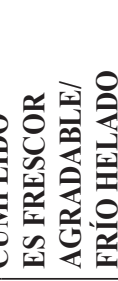 & 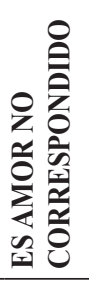 & & & & \\
\hline
\end{tabular}




\begin{tabular}{|c|c|c|c|c|c|c|c|}
\hline 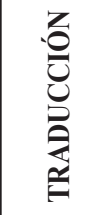 & & & & & & & \\
\hline 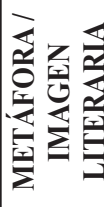 & & & & & & & \\
\hline 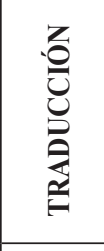 & 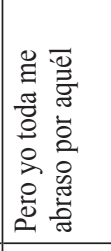 & 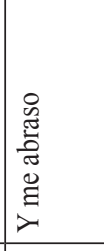 & 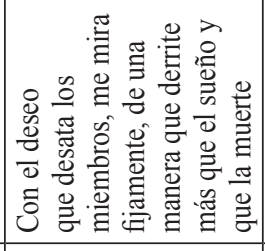 & 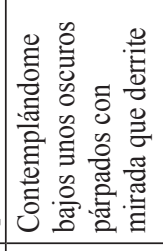 & 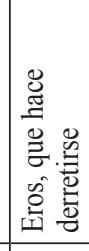 & 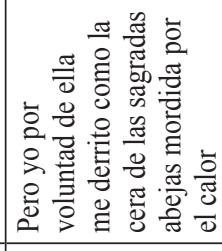 & 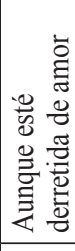 \\
\hline 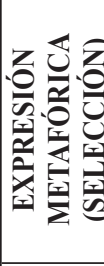 & 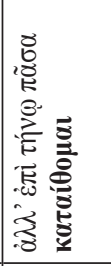 & 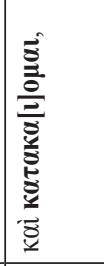 & 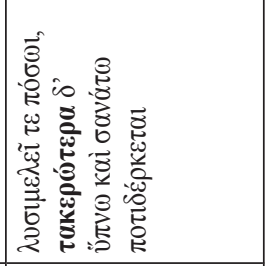 & 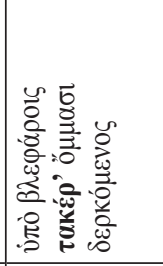 & 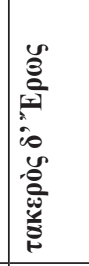 & 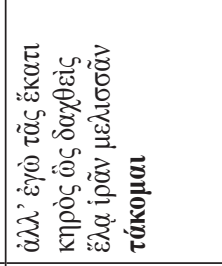 & 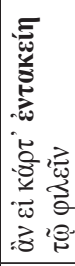 \\
\hline 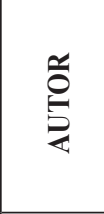 & 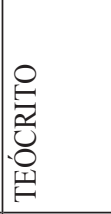 & $\mid$ & 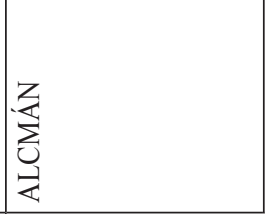 & $\stackrel{0}{0}$ & 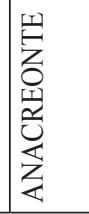 & 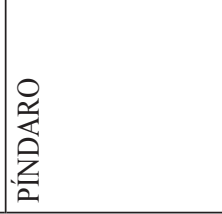 & 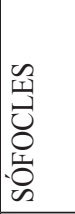 \\
\hline 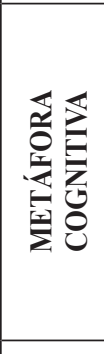 & 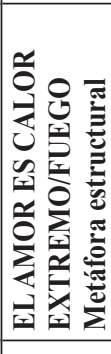 & 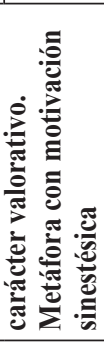 & 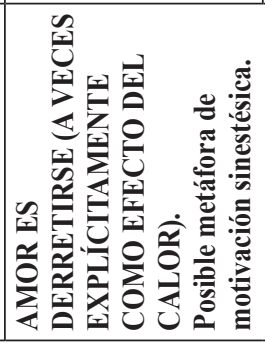 & & & & \\
\hline 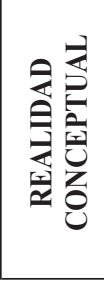 & 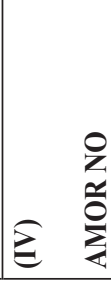 & 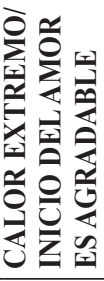 & 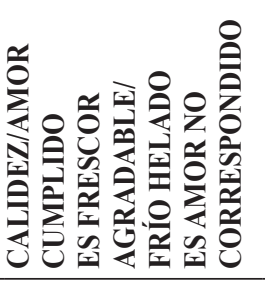 & & & & \\
\hline
\end{tabular}




\begin{tabular}{|c|c|c|c|c|c|c|c|c|c|c|c|}
\hline 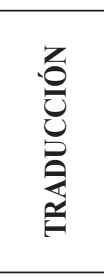 & & 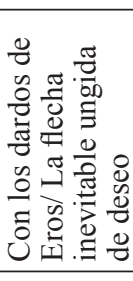 & 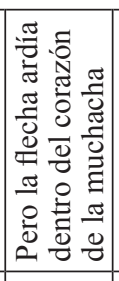 & & & & & & & & \\
\hline 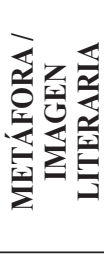 & & 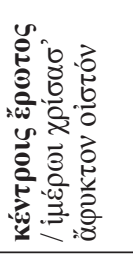 & 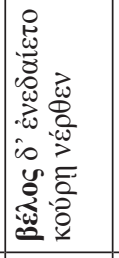 & & & & & & & & \\
\hline 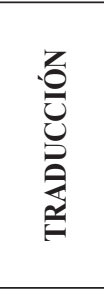 & 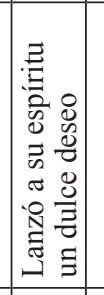 & & & 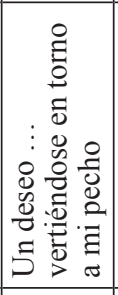 & 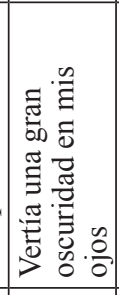 & 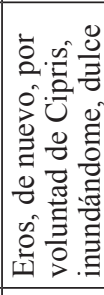 & 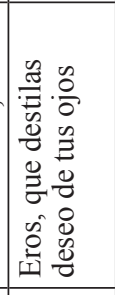 & 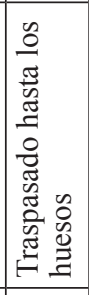 & 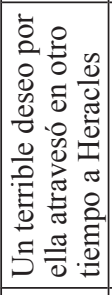 & 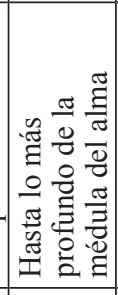 & 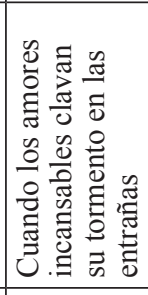 \\
\hline 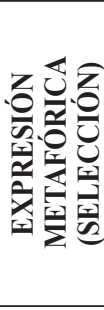 & 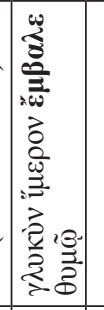 & & & 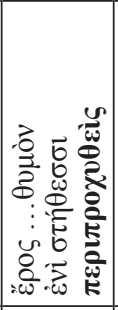 & 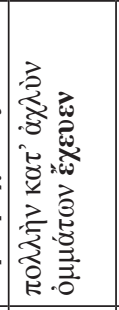 & 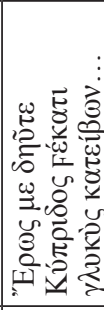 & 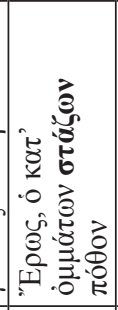 & 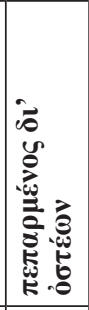 & 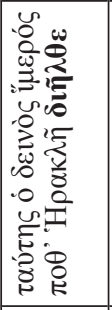 & 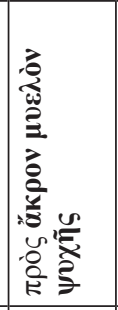 & 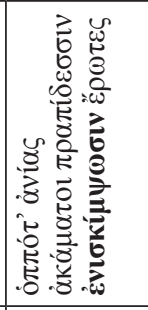 \\
\hline 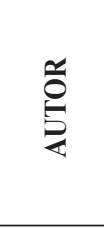 & $\begin{array}{l}\Xi \\
\Xi \\
\Sigma\end{array}$ & 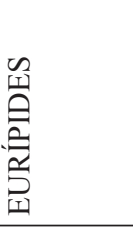 & 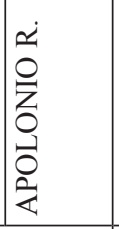 & 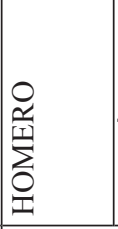 & 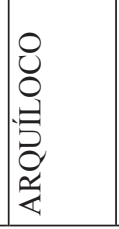 & 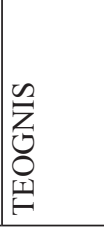 & 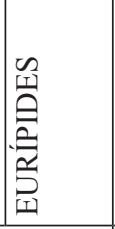 & 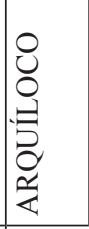 & 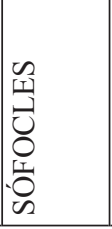 & 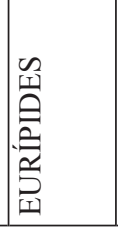 & \begin{tabular}{l}
0 \\
$z$ \\
0 \\
0 \\
0 \\
$\vdots$ \\
\multirow{z}{<}{}
\end{tabular} \\
\hline 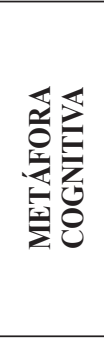 & 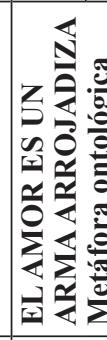 & & & 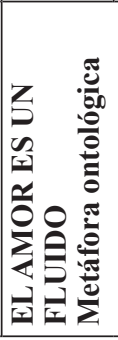 & & & & 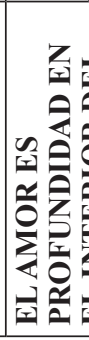 & 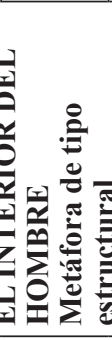 & & \\
\hline 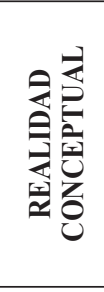 & $\varepsilon$ & 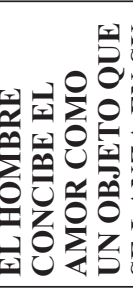 & $\frac{7}{2}$ & $\frac{2}{0}$ & & & & & & & \\
\hline
\end{tabular}




\begin{tabular}{|c|c|c|c|c|c|c|c|}
\hline 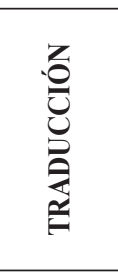 & & & & 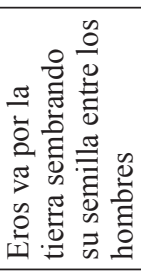 & 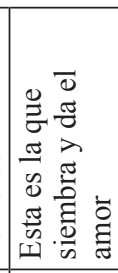 & & \\
\hline 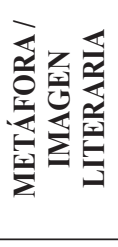 & & & & 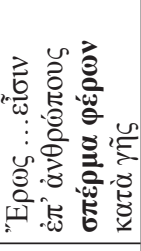 & 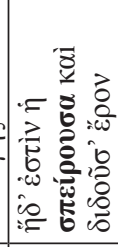 & & \\
\hline 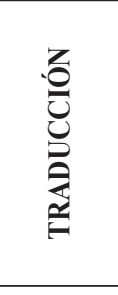 & 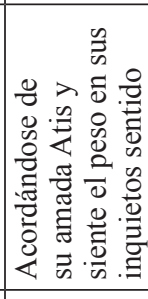 & 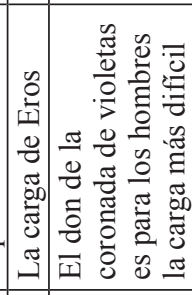 & 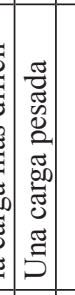 & & 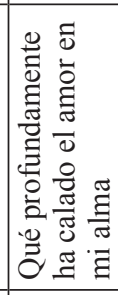 & 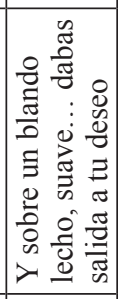 & 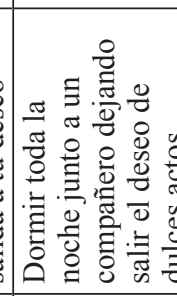 \\
\hline 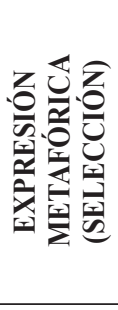 & 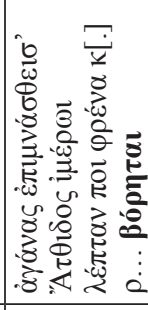 & 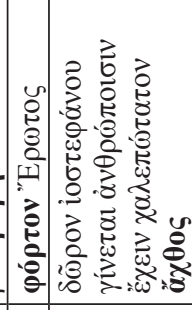 & 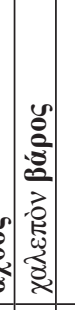 & & 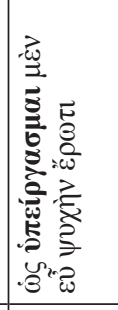 & 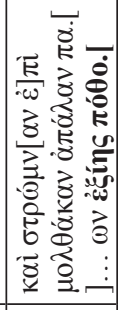 & 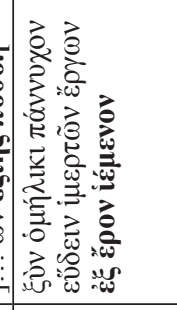 \\
\hline 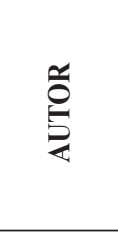 & $\begin{array}{l}0 \\
\text { 䍃 } \\
\text { 足 }\end{array}$ & 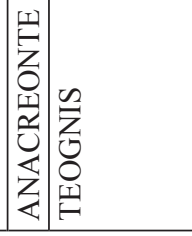 & 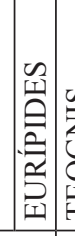 & 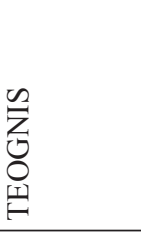 & 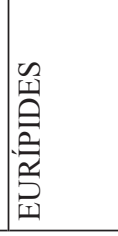 & \begin{tabular}{|l}
0 \\
至 \\
位
\end{tabular} & $\begin{array}{l}0 \\
Z \\
0 \\
0 \\
0 \\
1 \\
\end{array}$ \\
\hline 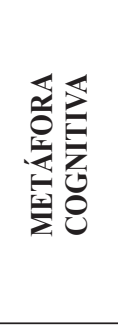 & 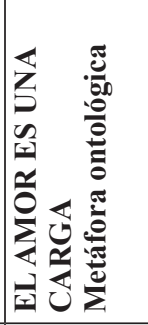 & & & 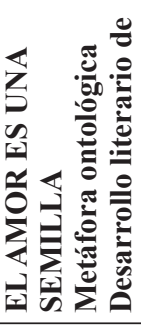 & $\approx$ & 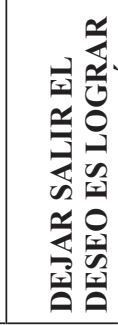 & \\
\hline 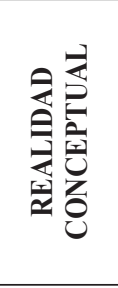 & 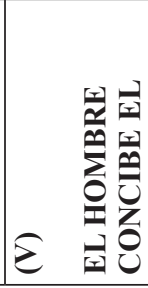 & 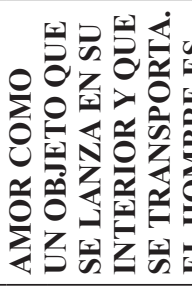 & 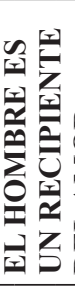 & 这 & & & \\
\hline
\end{tabular}




\begin{tabular}{|c|c|c|c|c|}
\hline 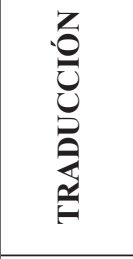 & 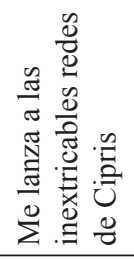 & & & \\
\hline 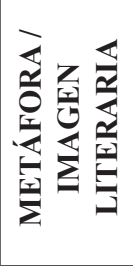 & 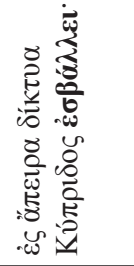 & & & \\
\hline 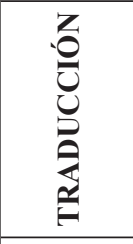 & & 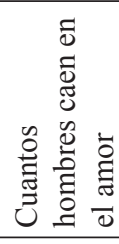 & 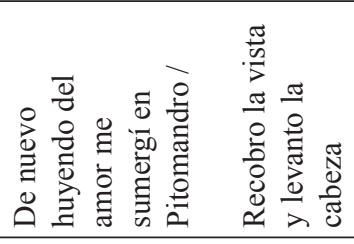 & 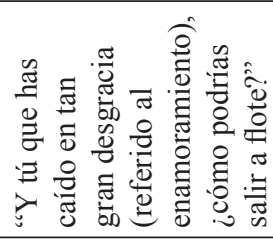 \\
\hline 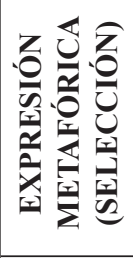 & & 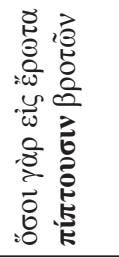 & 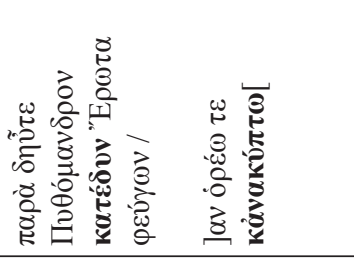 & 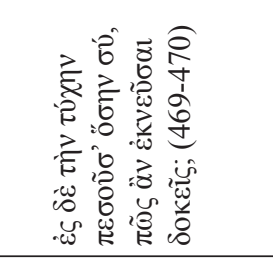 \\
\hline 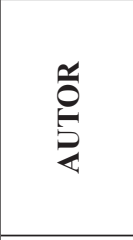 & $\begin{array}{l}\stackrel{0}{0} \\
. \oplus\end{array}$ & 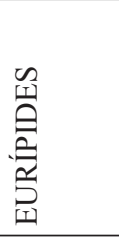 & 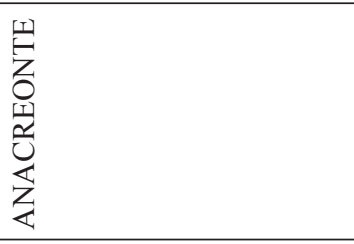 & $\begin{array}{l}\text { 留 } \\
\text { 囩 } \\
\text { 空 }\end{array}$ \\
\hline 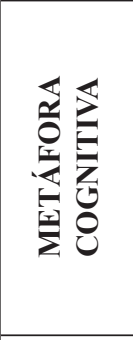 & 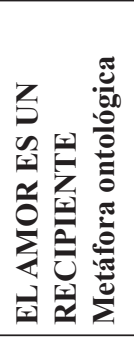 & & 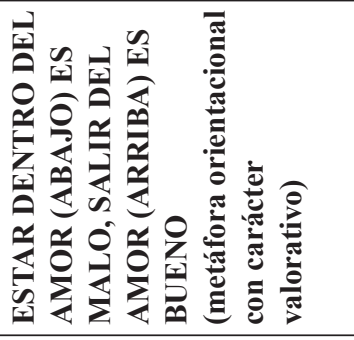 & \\
\hline 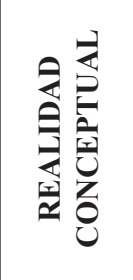 & 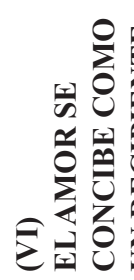 & 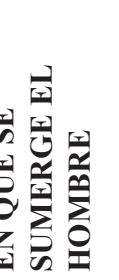 & & \\
\hline
\end{tabular}




\begin{tabular}{|c|c|c|c|c|c|c|}
\hline 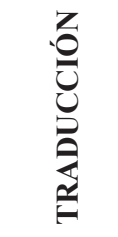 & & & & & & \\
\hline 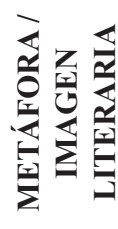 & & & & & & \\
\hline 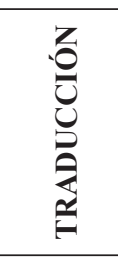 & 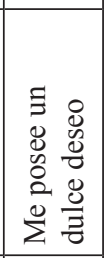 & 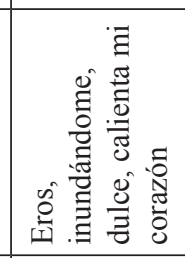 & 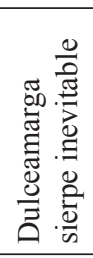 & 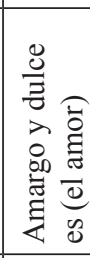 & 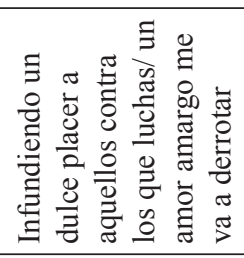 & 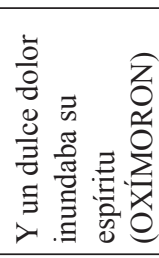 \\
\hline 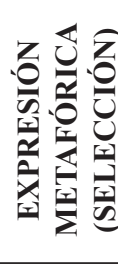 & 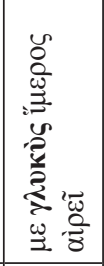 & 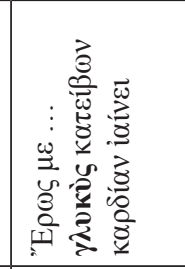 & 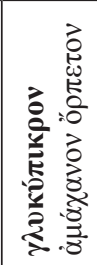 & 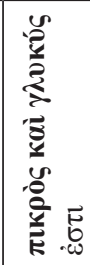 & 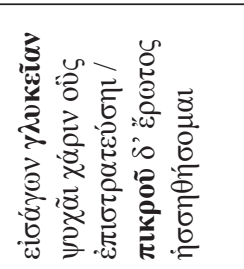 & 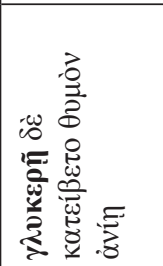 \\
\hline $\begin{array}{l}\stackrel{0}{0} \\
\stackrel{0}{2}\end{array}$ & $\begin{array}{l}0 \\
\frac{1}{11} \\
\sum \\
0 \\
0 \\
0\end{array}$ & 录 & $\begin{array}{l}0 \\
\text { 足 } \\
\text { Wn }\end{array}$ & 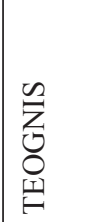 & 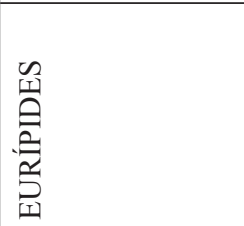 & 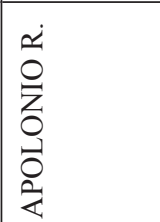 \\
\hline 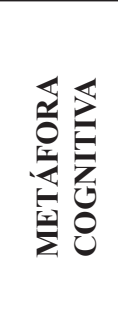 & 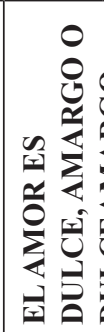 & 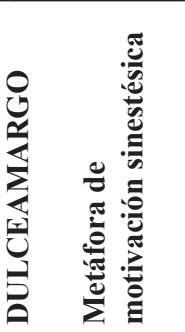 & & & & \\
\hline 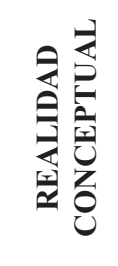 & $\hat{E}$ & 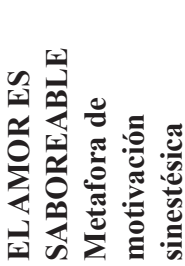 & & & & \\
\hline
\end{tabular}




\begin{tabular}{|c|c|c|c|c|c|}
\hline 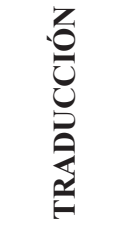 & & & & & \\
\hline 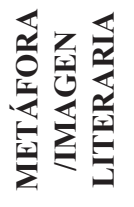 & & & & & \\
\hline 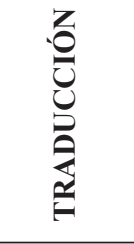 & 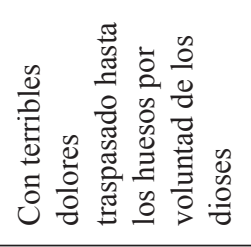 & 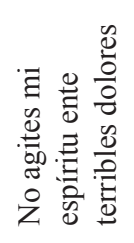 & 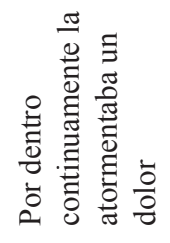 & 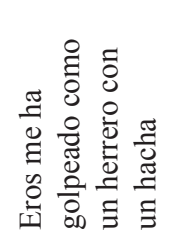 & 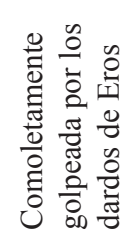 \\
\hline 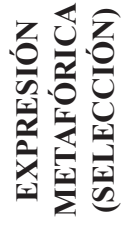 & 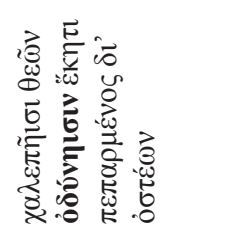 & 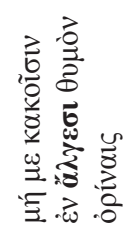 & 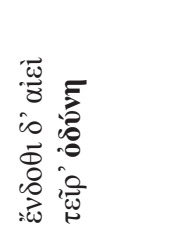 & 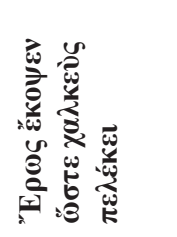 & 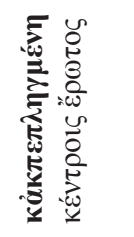 \\
\hline 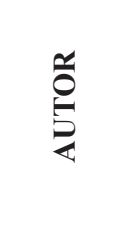 & 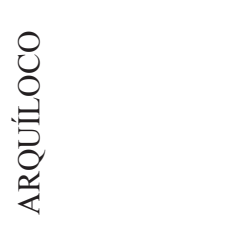 & 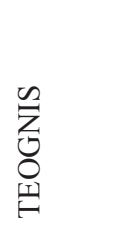 & 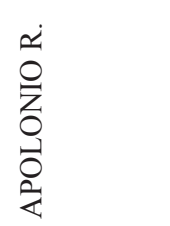 & 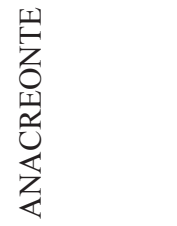 & 留 \\
\hline 窟造 & 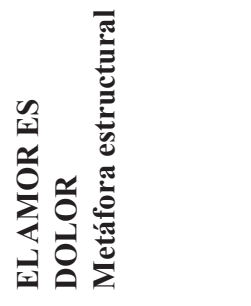 & & & 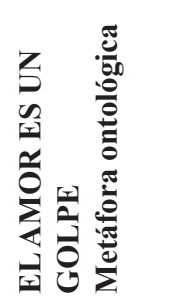 & \\
\hline 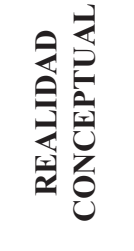 & 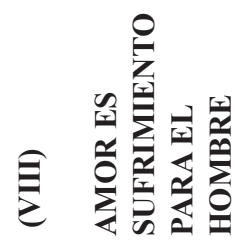 & & & & \\
\hline
\end{tabular}




\begin{tabular}{|c|c|c|c|c|c|c|c|}
\hline \begin{tabular}{l}
$Z$ \\
0 \\
0 \\
0 \\
0 \\
0 \\
\hdashline
\end{tabular} & 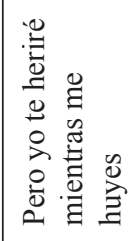 & & & & & & \\
\hline 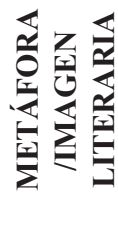 & 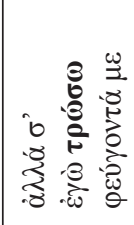 & & & & & & \\
\hline 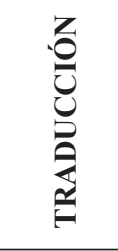 & & 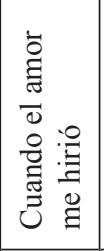 & 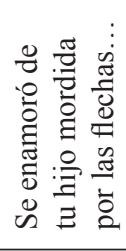 & 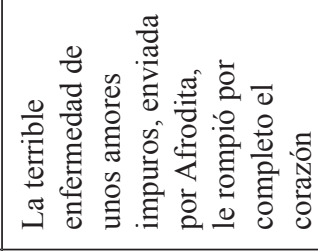 & 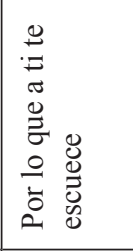 & 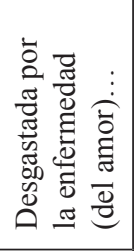 & 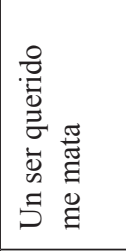 \\
\hline 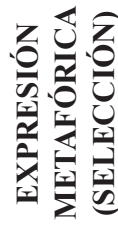 & & 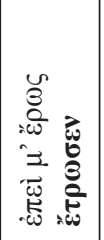 & 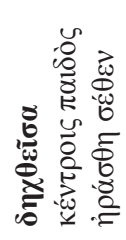 & 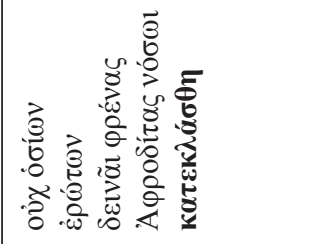 & 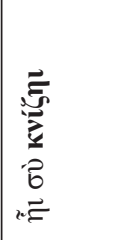 & 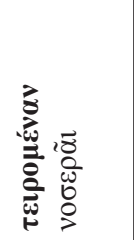 & 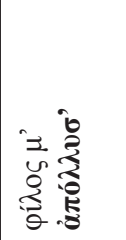 \\
\hline 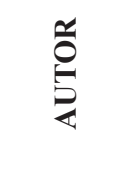 & 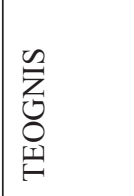 & 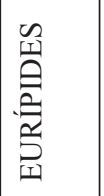 & 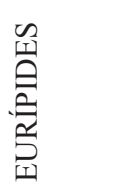 & 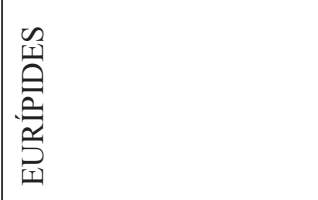 & 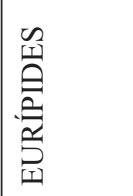 & 留 & 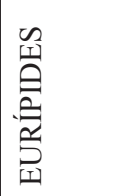 \\
\hline 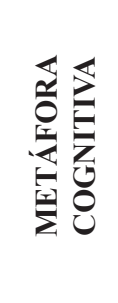 & 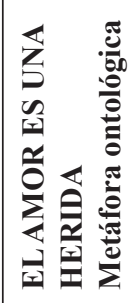 & & 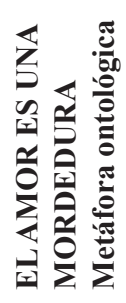 & 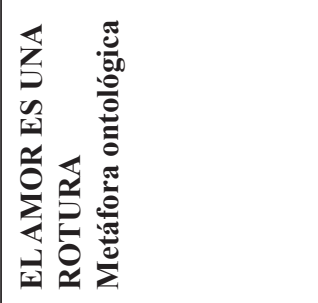 & 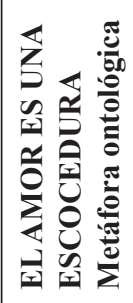 & 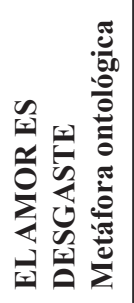 & 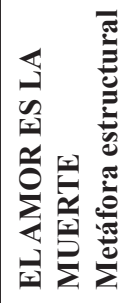 \\
\hline 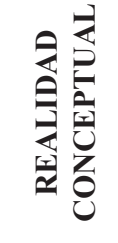 & $\hat{E}$ & 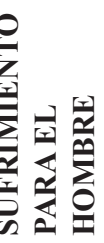 & & & & & \\
\hline
\end{tabular}




\begin{tabular}{|c|c|c|c|c|c|}
\hline 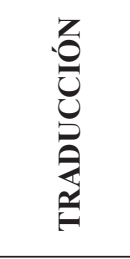 & 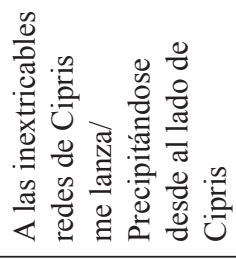 & & 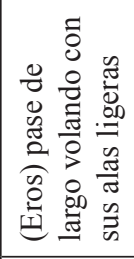 & & 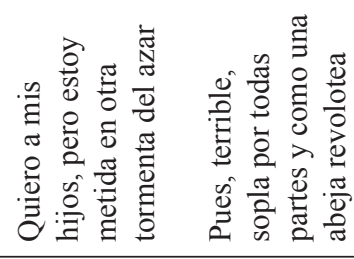 \\
\hline 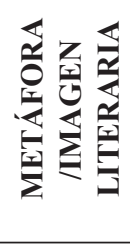 & 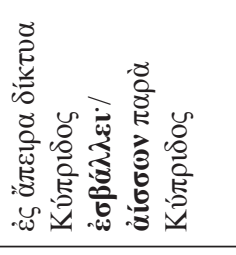 & & 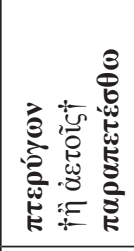 & & 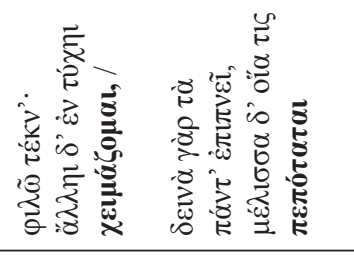 \\
\hline 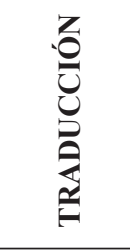 & & 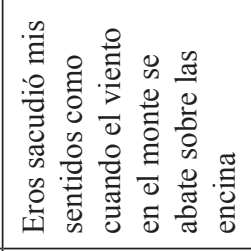 & & 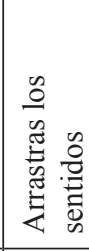 & 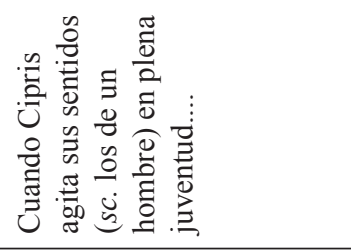 \\
\hline 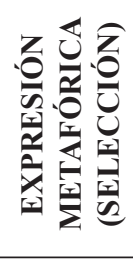 & & 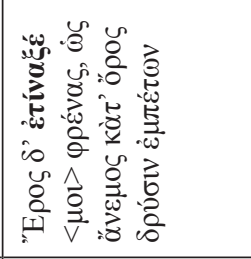 & & 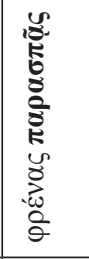 & 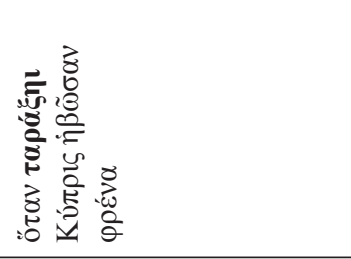 \\
\hline 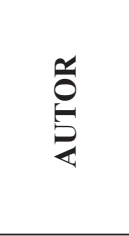 & $\stackrel{\ominus}{\mathscr{\theta}}$ & $\begin{array}{l}0 \\
\text { 主 } \\
\text { 足 }\end{array}$ & 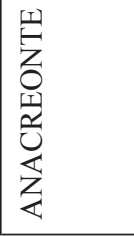 & 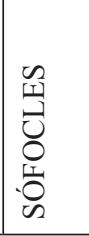 & 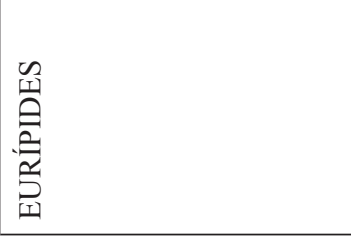 \\
\hline 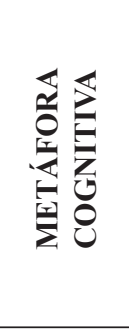 & 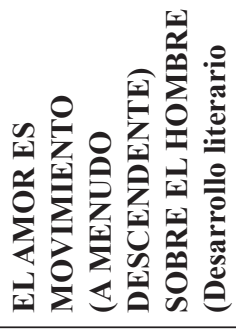 & 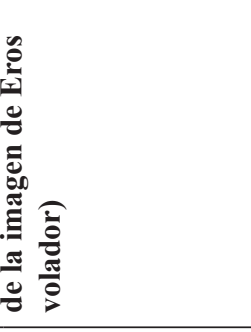 & & & \\
\hline 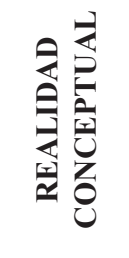 & 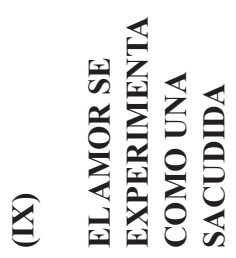 & 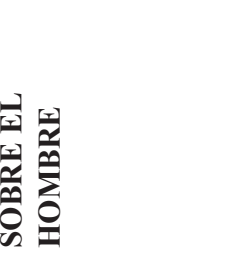 & & & \\
\hline
\end{tabular}




\begin{tabular}{|c|c|c|c|c|c|}
\hline 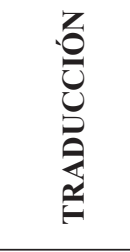 & 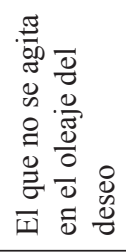 & & & & \\
\hline 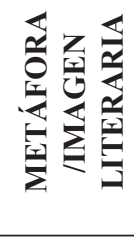 & 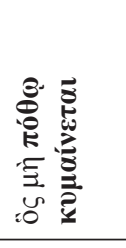 & & & & \\
\hline 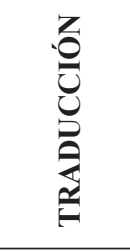 & & 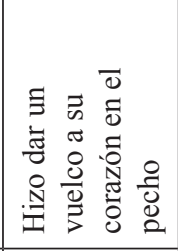 & 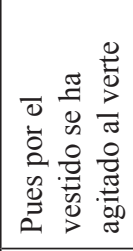 & 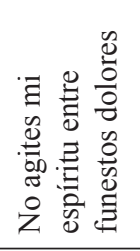 & 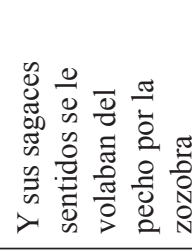 \\
\hline 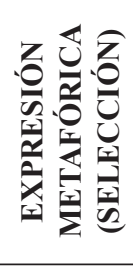 & & 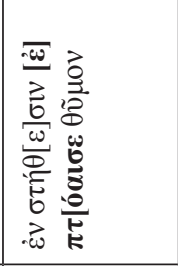 & 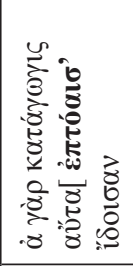 & 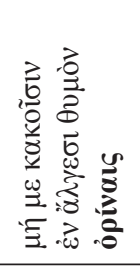 & 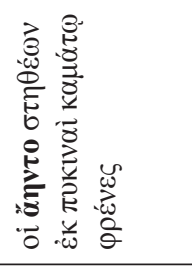 \\
\hline 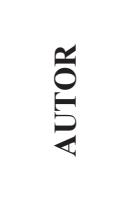 & 旁 & \begin{tabular}{|l}
0 \\
界 \\
罗
\end{tabular} & $\begin{array}{l}0 \\
\text { 茫 } \\
\text { nn }\end{array}$ & $\begin{array}{l}0 \\
Z \\
0 \\
0 \\
0 \\
1\end{array}$ & 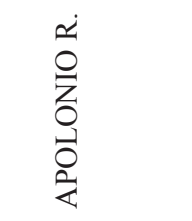 \\
\hline 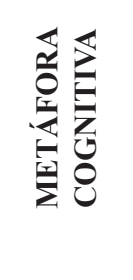 & 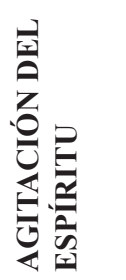 & & & & \\
\hline 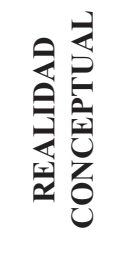 & 余 & 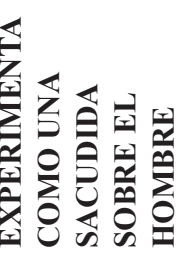 & & & \\
\hline
\end{tabular}




\begin{tabular}{|c|c|c|c|c|c|c|c|}
\hline 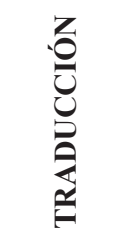 & & & & & & & \\
\hline 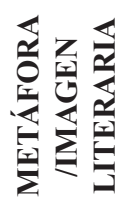 & & & & & & & \\
\hline 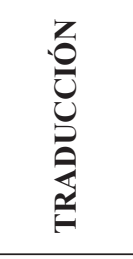 & 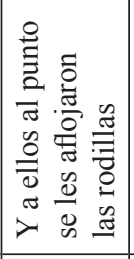 & 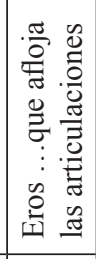 & 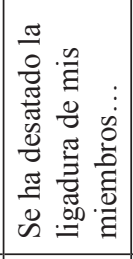 & 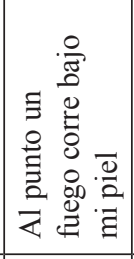 & 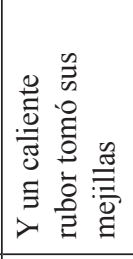 & 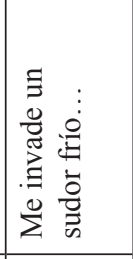 & 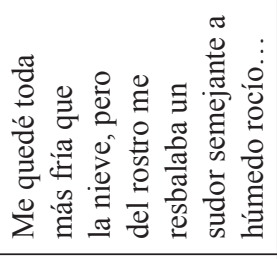 \\
\hline 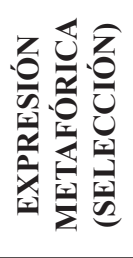 & 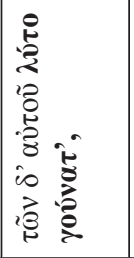 & 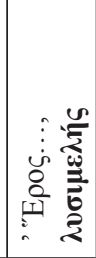 & 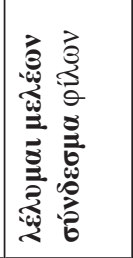 & 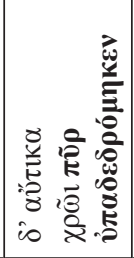 & 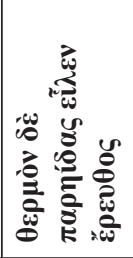 & 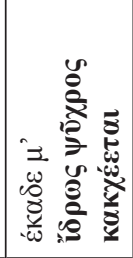 & 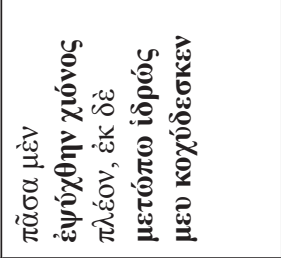 \\
\hline 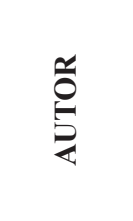 & 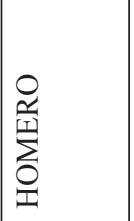 & 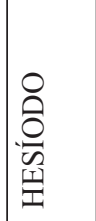 & 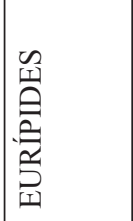 & $\begin{array}{l}0 \\
\text { 茫 } \\
\text { W }\end{array}$ & 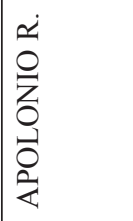 & $\begin{array}{l}0 \\
\text { 茫 } \\
\text { n }\end{array}$ & 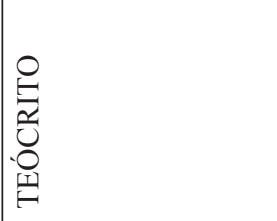 \\
\hline 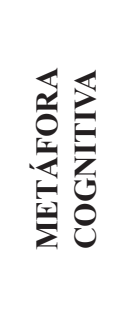 & 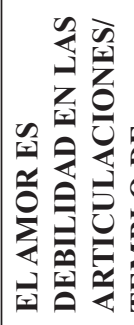 & 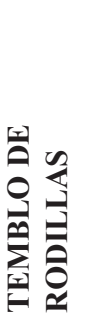 & & 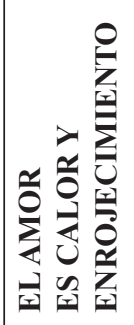 & & 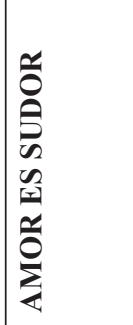 & \\
\hline 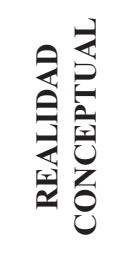 & (2) & 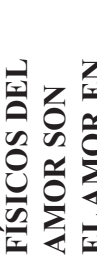 & 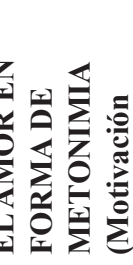 & 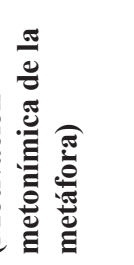 & & & \\
\hline
\end{tabular}




\begin{tabular}{|c|c|c|c|c|c|c|c|c|}
\hline $\begin{array}{l}Z \\
0 \\
0 \\
0 \\
0 \\
0 \\
\end{array}$ & & & & & & & & \\
\hline 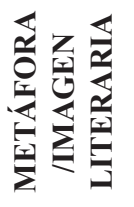 & & & & & & & & \\
\hline $\begin{array}{l}Z \\
0 \\
0 \\
0 \\
0 \\
0 \\
0\end{array}$ & 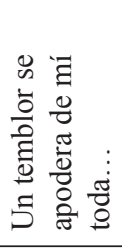 & 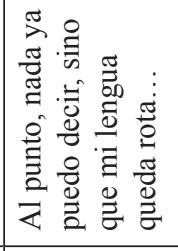 & 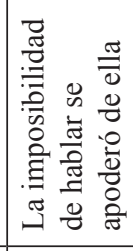 & 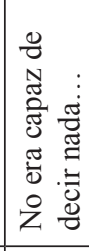 & 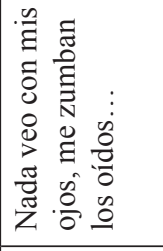 & 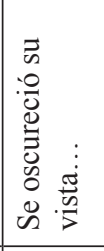 & 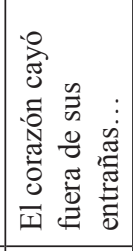 & 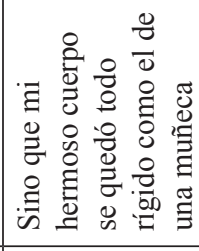 \\
\hline 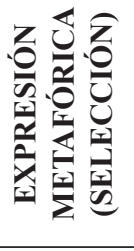 & 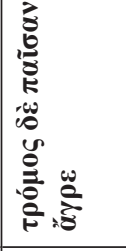 & 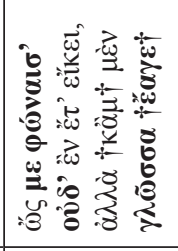 & 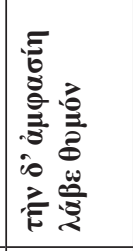 & 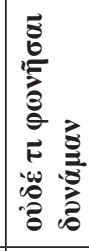 & 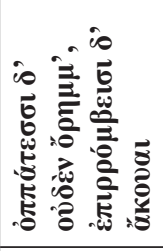 & 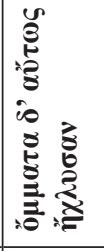 & 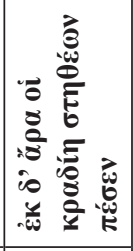 & 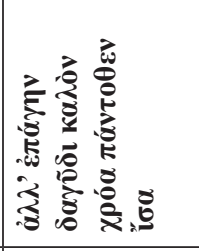 \\
\hline 号 & $\begin{array}{l}0 \\
\text { 丟 } \\
\text { 出 }\end{array}$ & $\begin{array}{l}0 \\
\text { 足 } \\
\text { 促 }\end{array}$ & 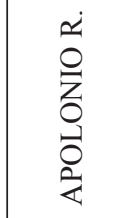 & 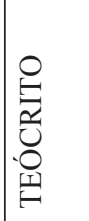 & $\begin{array}{l}0 \\
\text { 焉 } \\
\text { 足 }\end{array}$ & 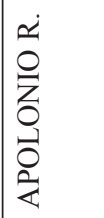 & 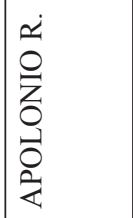 & 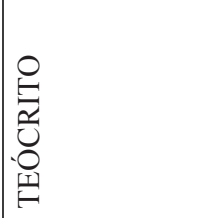 \\
\hline 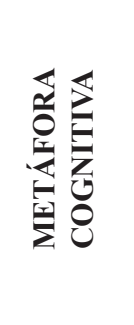 & 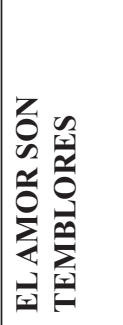 & 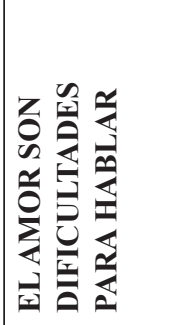 & & & 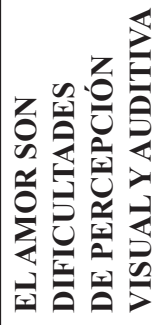 & & 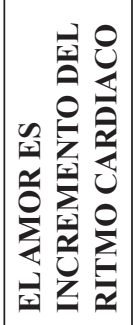 & 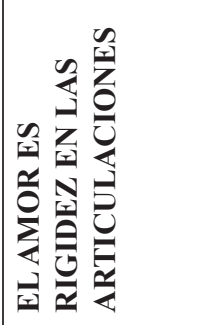 \\
\hline 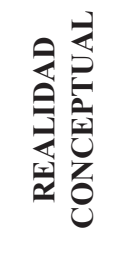 & $\begin{array}{l}n \\
\tilde{n} \\
0 \\
0\end{array}$ & 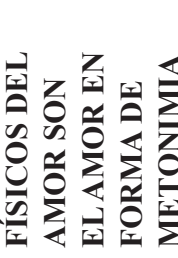 & 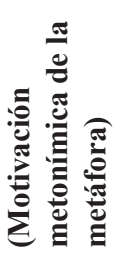 & & & & & \\
\hline
\end{tabular}

